\title{
Review Article \\ MicroRNAs-Dependent Regulation of PPARs in Metabolic Diseases and Cancers
}

\author{
Dorothea Portius, Cyril Sobolewski, and Michelangelo Foti \\ Department of Cell Physiology and Metabolism and Diabetes Center, Faculty of Medicine, University of Geneva, Geneva, Switzerland
}

Correspondence should be addressed to Michelangelo Foti; michelangelo.foti@unige.ch

Received 24 August 2016; Accepted 5 December 2016; Published 12 January 2017

Academic Editor: Valeria Amodeo

Copyright (C) 2017 Dorothea Portius et al. This is an open access article distributed under the Creative Commons Attribution License, which permits unrestricted use, distribution, and reproduction in any medium, provided the original work is properly cited.

\begin{abstract}
Peroxisome proliferator-activated receptors (PPARs) are a family of ligand-dependent nuclear receptors, which control the transcription of genes involved in energy homeostasis and inflammation and cell proliferation/differentiation. Alterations of PPARs' expression and/or activity are commonly associated with metabolic disorders occurring with obesity, type 2 diabetes, and fatty liver disease, as well as with inflammation and cancer. Emerging evidence now indicates that microRNAs (miRNAs), a family of small noncoding RNAs, which fine-tune gene expression, play a significant role in the pathophysiological mechanisms regulating the expression and activity of PPARs. Herein, the regulation of PPARs by miRNAs is reviewed in the context of metabolic disorders, inflammation, and cancer. The reciprocal control of miRNAs expression by PPARs, as well as the therapeutic potential of modulating PPAR expression/activity by pharmacological compounds targeting miRNA, is also discussed.
\end{abstract}

\section{Introduction}

Peroxisome proliferator-activated receptors (PPARs) are a family of nuclear receptors involved in various biological functions but with a prominent role in metabolic homeostasis of carbohydrates and lipids [1]. The three PPAR isoforms, PPAR $\alpha$ (NR1C1), PPAR $\beta / \delta$ (NR1C2), and PPAR $\gamma$ (NR1C3), share $60 \%$ to $80 \%$ of structural homology $[2,3]$ and exhibit a distinct tissue expression pattern but can exert similar or different physiological functions [3]. In the canonical model, PPARs are activated in the cytoplasm by specific ligands [1-6] and then translocate into the nucleus, where they form a complex predominantly with the nuclear receptor Retinoid-X-Receptor (RXR), to transactivate gene expression by binding to PPAR response elements (PPREs) on gene promoters [6, 7]. In contrast, noncanonical PPAR activity suppresses gene transcription through direct protein-protein interactions with other transcription factors, for example, the nuclear factor-kB (NFkB) or activated protein-1 (AP-1) $[1,3]$. PPARs activity is also tightly dependent on the binding of other cofactors such as PGCl $\alpha$ (peroxisome proliferatoractivated receptor coactivator- $1 \alpha$ ) and p 300 or CREB binding protein-or on the contrary on the binding of corepressor proteins, for example, NCOR (nuclear receptor corepressor) or SMRT (silencing mediator for retinoid and thyroid hormone receptor), which hamper PPARs interactions with PPRE [3].

Through complex regulatory mechanisms, PPARs exert a tight control on energy homeostasis by modulating the expression of key genes involved in lipid metabolism $[5,6]$, adipocytes differentiation [5], and carbohydrate metabolism $[5,6]$. The implication of PPARs in inflammatory processes and specific cancers is further suggested by recent studies (reviewed in $[3,8,9]$ ). These key and pleiotropic roles of PPARs in cellular processes have led to the development of pharmacologic agonists, for example, thiazolidinediones and fibrates $[10,11]$, to treat metabolic disorders or other diseases such as atherosclerosis [2, 5, 12]. However, long-term treatment with PPARs agonists triggers uncontrolled side effects in patients (e.g., oedema, weight gain, heart failure, and bone fractures) and in some cases they may even promote tumorigenesis $[6,8,13]$. Alternative therapeutic options to control distinct PPARs activities in specific tissues are therefore desirable but require that we deepen our understanding of the molecular mechanisms controlling PPARs expression/activity in diseases. 
Recently, a wealth of studies has suggested that epigenetic mechanisms, for example, DNA methylation, histone modifications, or small noncoding RNA (i.e., microRNAs), importantly affect physiological or pathological mechanisms involved in a wide variety of diseases and cancers. In the case of PPARs, methylation of their promoters $[14,15]$, or histone acetylation [16], has been reported to affect PPARs expression and physiological processes under their control. More recently, other epigenetic alterations, in particular those leading to abnormal microRNAs (miRNAs) expression, have also been implicated in the regulation of PPARs expression or activity [17]. Indeed several miRNAs were reported to either directly target PPARs mRNA or to indirectly affect their expression/activities by targeting PPARs-associated cofactors and repressors, thus providing a further level of complexity in these regulatory mechanisms [18-20].

In this review, we discuss the current knowledge about miRNAs-dependent regulation of PPARs and their cofactors in physiological and pathological processes. Most of available studies dealing with this topic are restrained to metabolic diseases (e.g., diabetes, fatty liver diseases, and cardiovascular diseases) and associated cancers (e.g., liver cancers) in tissues where the role of PPARs is well characterized (e.g., liver, adipose tissue, muscles, and heart). Other rare studies investigating PPARs regulation by miRNAs in different tissues (e.g., bone marrow, neurons, and cartilage) or type of cancers (e.g., neuroblastoma, prostate cancer), unrelated to metabolic disorders, are also considered. Finally, the reciprocal regulation of specific miRNAs by PPARs, as well as potential miRNAbased pharmacological approaches to therapeutically modulate PPARs expression and/or activity, was also examined.

\section{2. miRNAs}

MicroRNAs (miRNAs) are endogenous small noncoding RNAs of approximately 16-22 nucleotides, which bind to complementary sequences (seed sequences) in the $3^{\prime}$ UTR of target mRNAs and mediate either their decay or translation inhibition [21, 22]. miRNAs are encoded within intronic, intergenic regions or in polycistronic clusters $[19,23]$, and their biogenesis starts with a RNA polymerase II-dependent transcription of a primary transcript (pri-miRNA), which is then maturated by a nuclear microprocessor complex (RNase III Drosha and its mammalian double-stranded RNAbinding partner DGCR8). This leads to the release of a pre-miRNA, which is then exported into the cytoplasm by Exportin-5, where the RNase III Dicerl, together with its binding partner TARP2 (T-cell receptor gamma-chain constant region), removes the pre-miRNA hairpin loop and generates a miRNA duplex of mature miRNA (guide strand) and of a complementary strand (passenger strand or miRNA*). The guide strand and the miRNA* are then associated with Argonaute proteins and incorporated into the RNA-induced silencing complex (RISC). A second maturation step is initiated within the RISC to separate both strands and the mature miRNA binds to the $3^{\prime}$ UTR of target mRNAs. Recent evidence also indicates a pathophysiological role of the passenger strand of miRNA (miRNA ${ }^{*}$ ) in specific conditions, although it frequently appears to be degraded and devoid of any functions $[19,21,23,24]$.

More than 2000 miRNAs have been identified and it is considered that $60 \%$ of human genes are regulated by miRNAs with around 45000 miRNA targets within the transcriptome $[21-23,25]$. miRNAs act within an intricate regulatory network, where one specific miRNA can control the expression of several hundred mRNAs and conversely one mRNA can be targeted by several miRNAs $[19,23]$. Through their wide action, miRNAs are involved in the control of almost all cellular functions and alterations of their expression/activity are observed in various pathological conditions including metabolic diseases and associated cancers $[2,21$, 22, 25-29]. The bulk of the studies investigating PPARs and associated cofactors/repressors (e.g., RXR, NCOR) regulation by miRNAs has been performed in the frame of metabolic diseases, where the role of PPARs is the best characterized. Indeed, bioinformatics analyses using the miRWalk 2.0 platform (http://zmf.umm.uni-heidelberg.de/apps/zmf/mirwalk2/ index.html), which integrates different prediction software programs for miRNA-mRNA interactions, point to multiple candidate miRNAs potentially targeting directly PPAR isoforms. However, only a restricted number of these candidates have been validated by experimental approaches (see Table 1 ). Combining MetaCore ${ }^{\mathrm{TM}}$ and miRWalk 2.0 based analyses in human studies exclusively revealed that 606 miRNAs were implicated in human cancers, and among those 34 are in metabolic disorders (e.g., obesity, diabetes, hepatomegaly, fatty liver diseases, hypertension, dyslipidemia, and other diabetic complications). Among the 606 cancer-related miRNAs, eight were targeting PPAR $\alpha$, four were targeting $\operatorname{PPAR} \beta / \delta$, and eight were targeting $\operatorname{PPAR} \gamma$. Interestingly, two miRNAs targeting PPAR $\alpha$ (miR-21 and miR-519d) and two miRNAs targeting PPAR $\gamma$ (miR-27 and miR-20) were also previously associated with metabolic diseases (Figure 1). Although such predictive analyses using available software programs are subject to multiple biases and should be considered with extreme caution, they suggest that fine-tuning of PPARs signaling by miRNAs may sit at the crossroad between metabolic diseases and cancers in human.

\section{3. miRNAs-Dependent Regulation of PPARs in Metabolic Diseases and Cancer}

3.1. miRNAs-Dependent Regulation of PPAR $\alpha$. PPAR $\alpha$ is a nutritional sensor adapting metabolic homeostasis to energy deprivation [3]. It is mostly expressed in the liver, where it regulates lipid catabolism (i.e., $\beta$-oxidation) and critical genes (e.g., fatty acid transport protein 1, CD36, Acyl-CoA oxidase 1 , and Carnitine palmitoyltransferase 1) involved in fatty acid transport [68] and in ketogenesis (e.g., Hmgcs2, $\mathrm{Hmgcl}$ ) [68]. PPAR $\alpha$ exerts also an anti-inflammatory function, as evidenced in mouse models of acute inflammation [68]. This effect results from an attenuation of proinflammatory cytokines (e.g., Il-6, Il-1 $\beta$ ) expression as well as an upregulation of anti-inflammatory factors such as Il-1ra (Il-1 receptor antagonist) or $\mathrm{I} \kappa \mathrm{B} \alpha$ [68]. PPAR $\alpha$ is also expressed in other organs such as adipose tissues, heart, skeletal muscles, and kidneys, where it controls also some aspects of the glucose 
TABLE 1: Experimentally validated miRNAs targeting PPAR isoforms in specific tissues and pathophysiological processes.

(a) PPAR $\alpha$

\begin{tabular}{|c|c|c|c|}
\hline miRNA & Biological process & Cell/tissue & Reference \\
\hline \multicolumn{4}{|c|}{ Human studies } \\
\hline \multirow{2}{*}{ miR-9 } & $\begin{array}{c}\text { Cancer cell invasion and } \\
\text { proliferation }\end{array}$ & $\begin{array}{c}\text { HCC tissue } \\
\text { Hepatic cell lines }\end{array}$ & $\begin{array}{c}\text { Drakaki et al., } 2015 \\
{[30]}\end{array}$ \\
\hline & Lipid metabolism & $\begin{array}{c}\text { HCC tissue } \\
\text { Hepatic cell lines }\end{array}$ & Cui et al., 2015 [31] \\
\hline miR-10b & Hepatic steatosis & Hepatic cell lines & $\begin{array}{l}\text { Zheng et al., } 2010 \\
\text { [32] }\end{array}$ \\
\hline \multirow[b]{2}{*}{$\operatorname{miR}-21$} & Vascular inflammation & Endothelial cell lines & $\begin{array}{c}\text { Zhou et al., } 2011 \\
{[33]}\end{array}$ \\
\hline & $\begin{array}{l}\text { Liver cell injury } \\
\text { Inflammation } \\
\text { Fibrosis }\end{array}$ & $\begin{array}{c}\text { Liver tissue } \\
\text { Primary biliary and hepatic } \\
\text { inflammatory cells }\end{array}$ & $\begin{array}{l}\text { Loyer et al., } 2015 \\
\text { [34] }\end{array}$ \\
\hline miR-33 & Liver fibrosis & Hepatic stellate cell line & Li et al., 2014 [35] \\
\hline miR-141-3p & HBV replication & Hepatic cell line & Hu et al., 2012 [36] \\
\hline miR-199a-5p & Hepatic steatosis & $\begin{array}{c}\text { Liver tissue } \\
\text { Hepatic cell lines }\end{array}$ & Li et al., 2014 [37] \\
\hline miR-506 & Drug resistance & Colon cancer cell line & $\begin{array}{c}\text { Tong et al., } 2011 \\
{[38]}\end{array}$ \\
\hline miR-519d & Adipocyte differentiation & $\begin{array}{c}\text { White adipose tissue } \\
\text { Primary preadipocytes }\end{array}$ & $\begin{array}{l}\text { Martinelli et al., } \\
2010[39]\end{array}$ \\
\hline \multicolumn{4}{|c|}{ Rodent studies } \\
\hline miR-21 & $\begin{array}{l}\text { Liver cell injury } \\
\text { Inflammation } \\
\text { Fibrosis }\end{array}$ & $\begin{array}{c}\text { Liver tissue } \\
\text { Primary biliary and hepatic } \\
\text { inflammatory cells }\end{array}$ & $\begin{array}{l}\text { Loyer et al., } 2015 \\
\qquad[34]\end{array}$ \\
\hline $\operatorname{miR}-22$ & $\begin{array}{l}\text { Cardiac hypertrophy } \\
\text { Cardiac contractility }\end{array}$ & $\begin{array}{c}\text { Heart tissue } \\
\text { Primary neonatal } \\
\text { cardiomyocytes }\end{array}$ & $\begin{array}{c}\text { Gurha et al., } 2013 \\
{[40]}\end{array}$ \\
\hline $\operatorname{miR}-27$ & Adipocyte differentiation & $\begin{array}{c}\text { Brown/white adipose tissue, } \\
\text { primary adipose derived stromal } \\
\text { cells, } \\
\text { brown preadipocyte cell line }\end{array}$ & Sun et al., 2014 [41] \\
\hline miR-124-3p & Protein secretion & Isolated neutrophils & $\begin{array}{c}\text { Baek et al., } 2008 \\
\text { [42] }\end{array}$ \\
\hline miR-199a-5p & Hepatic steatosis & $\begin{array}{c}\text { Liver tissue } \\
\text { Hepatic cell lines }\end{array}$ & Li et al., 2014 [37] \\
\hline \multicolumn{4}{|c|}{ (b) $\mathrm{PPAR} \beta / \delta$} \\
\hline miRNA & Biological process & Cell/tissue & Reference \\
\hline \multicolumn{4}{|c|}{ Human studies } \\
\hline $\begin{array}{l}\text { miR-199a } \\
\text { miR-214 }\end{array}$ & Mitochondrial metabolism & $\begin{array}{c}\text { Myocardium } \\
\text { Primary cardiomyocytes }\end{array}$ & $\begin{array}{c}\text { El Azzouzi et al., } 2013 \\
{[43]}\end{array}$ \\
\hline miR-9 & Inflammation & Isolated monocytes & Thulin et al., 2013 [44] \\
\hline miR-138 & $\begin{array}{l}\text { Wound healing, } \\
\text { Proliferation, migration }\end{array}$ & $\begin{array}{l}\text { Skin tissue } \\
\text { Hypertrophic scar } \\
\text { fibroblasts }\end{array}$ & Xiao et al., 2015 [45] \\
\hline \multicolumn{4}{|c|}{ Rodent studies } \\
\hline $\begin{array}{l}\mathrm{miR}-199 \mathrm{a} \\
\mathrm{miR}-214\end{array}$ & Mitochondrial metabolism & $\begin{array}{c}\text { Myocardium } \\
\text { Primary cardiomyocytes }\end{array}$ & $\begin{array}{c}\text { El Azzouzi et al., } 2013 \\
{[43]}\end{array}$ \\
\hline \multicolumn{4}{|c|}{ (c) $\operatorname{PPAR} \gamma$} \\
\hline miRNA & Biological process & Cell/tissue & Reference \\
\hline \multicolumn{4}{|c|}{ Human studies } \\
\hline miR-20 & Osteogenic differentiation & $\begin{array}{c}\text { Bone marrow derived } \\
\text { stromal cell line }\end{array}$ & $\begin{array}{c}\text { Zhang et al., } 2011 \\
{[46]}\end{array}$ \\
\hline
\end{tabular}


(c) Continued.

\begin{tabular}{|c|c|c|c|}
\hline miRNA & Biological process & Cell/tissue & Reference \\
\hline \multirow[b]{2}{*}{$\operatorname{miR}-27 a$} & Proliferation & $\begin{array}{c}\text { HCC tissue } \\
\text { Hepatic cell lines }\end{array}$ & Li et al., 2015 [47] \\
\hline & Proliferation & $\begin{array}{c}\text { Lung tissue } \\
\text { Pulmonary endothelial } \\
\text { cell lines }\end{array}$ & $\begin{array}{c}\text { Kang et al., } 2013 \\
{[48]}\end{array}$ \\
\hline \multirow{3}{*}{ miR-27b } & Inflammation & $\begin{array}{l}\text { Isolated monocytes } \\
\text { Monocyte cell line }\end{array}$ & $\begin{array}{l}\text { Jennewein et al., } \\
2010 \text { [49] }\end{array}$ \\
\hline & Adipocyte differentiation & $\begin{array}{l}\text { Adipose derived stromal } \\
\text { cell line }\end{array}$ & $\begin{array}{l}\text { Karbiener et al., } \\
2009[50]\end{array}$ \\
\hline & $\begin{array}{c}\text { Tumor growth and } \\
\text { progression }\end{array}$ & Neuroblastoma cell line & Lee et al., 2012 [51] \\
\hline $\begin{array}{l}\mathrm{miR}-34 \mathrm{a} \\
\mathrm{miR}-34 \mathrm{c}\end{array}$ & Liver fibrosis & 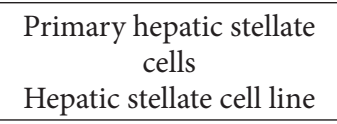 & Li et al., 2015 [52] \\
\hline miR-128-3p & Liver fibrosis & 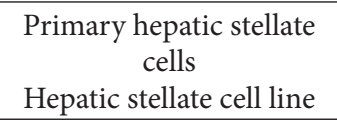 & $\begin{array}{c}\text { Povero et al., } 2015 \\
{[53]}\end{array}$ \\
\hline \multirow{2}{*}{ miR-130 } & Adipocyte differentiation & Primary preadipocytes & Lee et al., 2011 [54] \\
\hline & $\begin{array}{l}\text { Epithelial-mesenchymal } \\
\text { transition } \\
\text { Cancer cell migration and } \\
\text { invasion }\end{array}$ & $\begin{array}{c}\text { HCC tissue } \\
\text { Hepatic cell lines }\end{array}$ & Tu et al., 2014 [55] \\
\hline miR-130a & Type 2 diabetes mellitus & $\begin{array}{l}\text { White adipose tissue } \\
\text { Adipocyte cell line }\end{array}$ & Jiao et al., 2015 [56] \\
\hline miR-138 & Adipocyte differentiation & $\begin{array}{c}\text { Primary adipose derived } \\
\text { stromal cells }\end{array}$ & $\begin{array}{c}\text { Yang et al., } 2011 \\
{[57]}\end{array}$ \\
\hline miR-548d-5p & Adipocyte differentiation & $\begin{array}{c}\text { Bone marrow derived } \\
\text { stromal cells }\end{array}$ & Sun et al., 2014 [58] \\
\hline \multicolumn{4}{|c|}{ Rodent studies } \\
\hline \multirow{2}{*}{ miR-27 } & Adipocyte differentiation & $\begin{array}{l}\text { White adipose tissue, } \\
\text { Primary white } \\
\text { adipocytes } \\
\text { Primary adipose derived } \\
\text { stromal cells } \\
\text { Preadipocyte cell line }\end{array}$ & $\begin{array}{c}\text { Kim et al., } 2010 \\
{[59]}\end{array}$ \\
\hline & Adipocyte differentiation & $\begin{array}{l}\text { Brown/white adipose } \\
\text { tissue } \\
\text { Primary adipose derived } \\
\text { stromal cells } \\
\text { Brown pre-adipocyte cell } \\
\text { line }\end{array}$ & Sun et al., 2014 [41] \\
\hline \multirow{2}{*}{ miR-27a } & Proliferation & $\begin{array}{c}\text { Lung tissue } \\
\text { Pulmonary endothelial } \\
\text { cell lines }\end{array}$ & $\begin{array}{c}\text { Kang et al., } 2013 \\
{[48]}\end{array}$ \\
\hline & Renal fibrosis & $\begin{array}{c}\text { Kidney tissue } \\
\text { Kidney tubular epithelial } \\
\text { cells }\end{array}$ & $\begin{array}{l}\text { Hou et al., } 2016 \\
{[60]}\end{array}$ \\
\hline $\operatorname{miR}-27 b$ & $\begin{array}{c}\text { Cardiac hypertrophy } \\
\text { Heart failure }\end{array}$ & $\begin{array}{c}\text { Myocardium } \\
\text { Primary cardiomyocytes }\end{array}$ & $\begin{array}{c}\text { Wang et al., } 2012 \\
{[61]}\end{array}$ \\
\hline $\begin{array}{l}\text { miR-34a } \\
\text { miR-34c }\end{array}$ & Liver fibrosis & 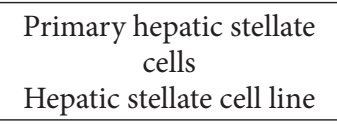 & Li et al., 2015 [52] \\
\hline miR-128-3p & Liver fibrosis & $\begin{array}{c}\text { Primary hepatic stellate } \\
\text { cells } \\
\text { Hepatic stellate cell line }\end{array}$ & $\begin{array}{l}\text { Povero et al., } 2015 \\
\text { [53] }\end{array}$ \\
\hline
\end{tabular}


(c) Continued.

\begin{tabular}{lccc}
\hline miRNA & Biological process & Cell/tissue & Reference \\
\hline miR-130 & Adipocyte inflammation & Treadipocyte cell line & Kim et al., 2013 [62] \\
& Liver fibrosis & $\begin{array}{c}\text { Primary hepatic stellate } \\
\text { cells } \\
\text { Hepatic stellate cell line }\end{array}$ & Lu et al., 2015 [63] \\
miR-130a & Type 2 diabetes mellitus & $\begin{array}{c}\text { White adipose tissue } \\
\text { Adipocyte cell line }\end{array}$ & Jiao et al., 2015 [56] \\
\hline miR-210 & Osteoporosis & $\begin{array}{c}\text { Primary bone marrow } \\
\text { derived stromal cells }\end{array}$ & Liu et al., 2015 [64] \\
\hline miR-301a & Adipocyte inflammation & $\begin{array}{c}\text { White adipose tissue } \\
\text { Preadipocyte cell line }\end{array}$ & Li et al., 2016 [65] \\
\hline miR-302a & Adipocyte differentiation & $\begin{array}{c}\text { White adipose tissue } \\
\text { Pre-adipocyte cell line }\end{array}$ & Jeong et al., 2014 [66] \\
\hline miR-540 & Adipocyte differentiation & $\begin{array}{c}\text { Primary adipose derived } \\
\text { stromal cells }\end{array}$ & Chen et al., 2015 [67] \\
\hline
\end{tabular}

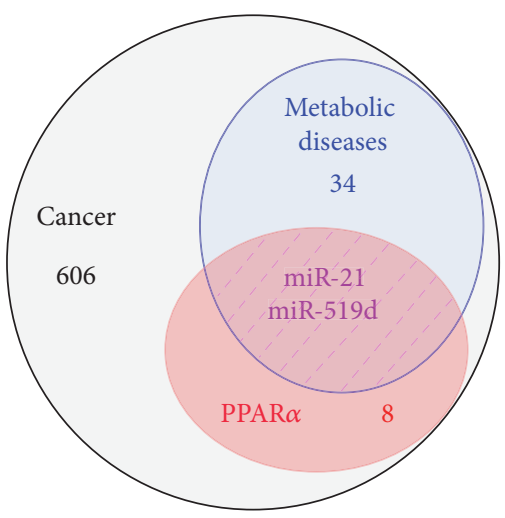

(a)

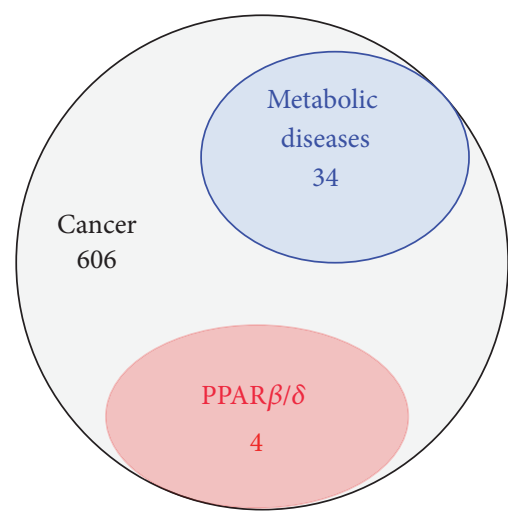

(b)

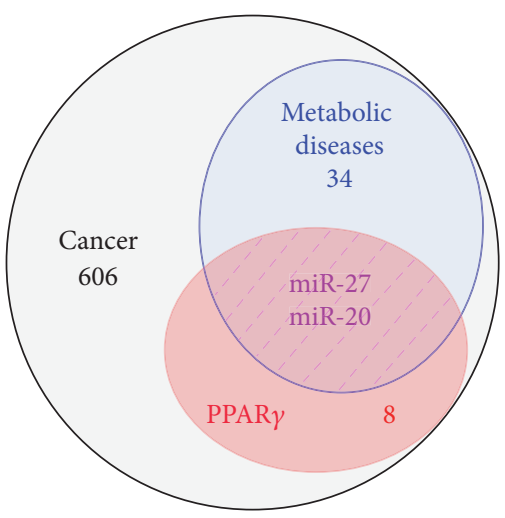

(c)

FIGURE 1: Human miRNAs targeting PPAR isoforms and involved in metabolic diseases and cancer. MetaCore pathway analysis software from Thomson Reuters was used to identify experimentally the number of validated human miRNAs involved in cancer (grey circle). Among those, the numbers of miRNAs involved in metabolic diseases, also identified by MetaCore pathway analysis, are indicated in blue circles. In red circles are the number of miRNAs identified using miRWalk 2.0 atlas and targeting PPAR $\alpha$ (Panel (a)), PPAR $\beta / \delta$ (Panel (b)), and PPAR $\gamma$ (Panel (c)). The identities of miRNAs targeting specific PPAR isoforms and involved in both cancer and metabolic diseases are indicated in violet. miRWalk 2.0 atlas is a software integrating 12 different prediction algorithms (miRWalk 2.0, MicroT4, miRanda, miRBridge, miRDB, miRMap, miRNAMap, PICTAR2, PITA, RNA22, RNAhybrid, and TargetScan) for identification of miRNAs target mRNAs.

and lipid homeostasis (i.e., $\beta$-oxidation) $[6,68,69]$. PPAR $\alpha$ is usually activated through the binding of specific ligands, in particular unsaturated fatty acids ( $\omega$-3 fatty acids), eicosanoid derivatives (e.g., 8-hydroxy-eicosatetraenoic acid, prostacyclin), or metabolized fatty acids (e.g., oxidized fatty acids) [6]. Alterations of PPAR $\alpha$ expression or activity were associated with a variety of human pathologies such as obesity, liver diseases, inflammation, and cancers [3, 68, 69]. It is now clear that deregulations of specific miRNA can significantly contribute to PPAR $\alpha$ abnormal signaling in these pathophysiological conditions (see experimentally validated miRNAs targeting PPAR $\alpha$ in Table 1 and Figure 2). Such alterations have been investigated only in specific tissues, such as the liver or adipose tissue, as well as in inflammatory cells and cartilage and specific tumors (e.g., in the colon). Whether PPAR $\alpha$ expression/activity is affected by miRNAs in other metabolically active tissues, for example, skeletal muscles or pancreas, remains to be established.

3.1.1. miRNAs-Dependent Regulation of PPAR $\alpha$ in the Liver. In the liver, PPAR $\alpha$ is implicated in the lipid catabolism and inflammatory processes [68]. miRNAs-dependent alterations of PPAR $\alpha$ signaling are reported by numerous studies to contribute to the onset of liver diseases such as nonalcoholic fatty liver disease (NAFLD) [19, 21, 29], chronic diseases associated with viral infections (HBV, HCV) [70], or hepatic cancers $[30,71]$.

Hepatic Steatosis. Two miRNAs were shown to alter PPAR $\alpha$ expression in hepatocytes and to lead to steatosis development (Table 1) [19, 69]. Upregulation of miR-199a-5p was observed in various in vivo mouse models of obesity (ob/ob 


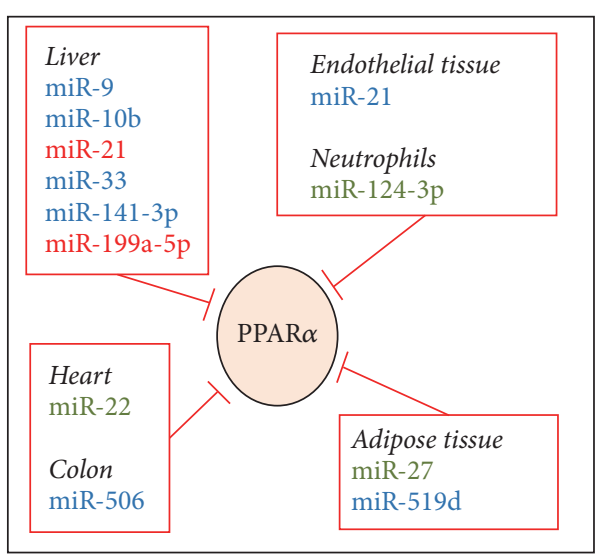

(a)

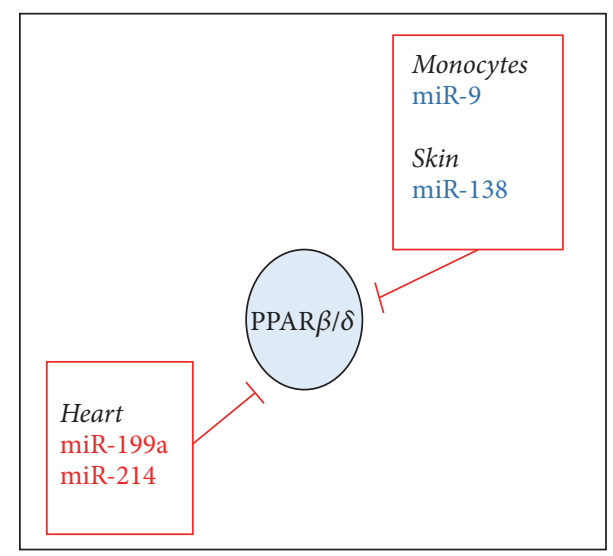

(b)

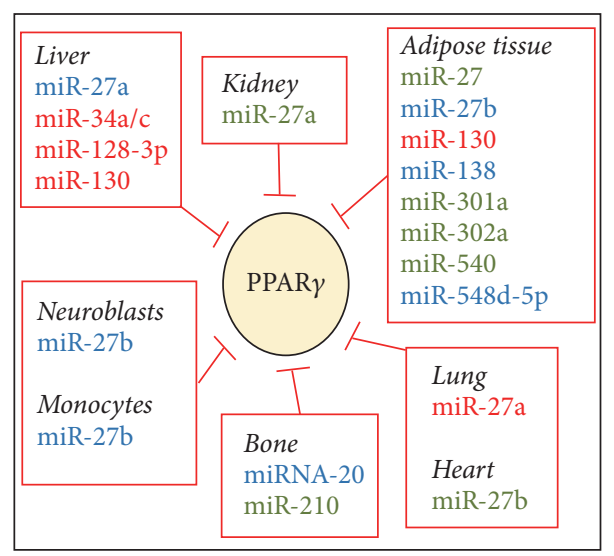

(c)

FIGURE 2: miRNAs targeting PPAR isoforms in specific tissues. miRNAs (also referred to in Table 1) that have been experimentally demonstrated to specifically target PPAR $\alpha$ (Panel (a)), PPAR $\beta / \delta$ (Panel (b)), and PPAR $\gamma(\operatorname{Panel}(\mathrm{c}))$ in different tissues are illustrated. miRNAs identified in human studies are in blue, those identified in mouse/rat studies are in green, and those identified in both human and rodents studies are in red.

and $\mathrm{db} / \mathrm{db}$ mice, mice fed a high-fat diet), as well as in liver samples from patients with NAFLD. In vitro analyses of hepatoma cell lines (HepG2 and murine AML12 cells) exposed to fatty acids as a surrogate model of steatosis further confirm an upregulation of miR-199a-5p, which in turn downregulates $\operatorname{PPAR} \alpha$ and caveolin-1 thereby promoting abnormal cellular redox equilibrium and fatty acids intracellular accumulation [37]. In human hepatic LO2 cells, Zheng et al. uncover another miRNA, miR-10b, upregulated following exposure to fatty acids and having a unique binding site in the PPAR $\alpha$ $3^{\prime} \mathrm{UTR}$ sequence [32]. However, the relevance of miR-10b alterations in human liver metabolic disorders was not evaluated.

Hepatic Inflammation and Fibrosis. PPAR $\alpha$ downregulation by miRNAs was recently suggested to trigger hepatic inflammation and fibrosis. Indeed, Loyer et al. [34] reported an upregulation of miR-21 in biliary and inflammatory cells of mice and patients with nonalcoholic steatohepatitis (NASH). They further discover that miR-21 was promoting hepatic inflammation and fibrosis by suppressing PPAR $\alpha$ expression in these cells. Interestingly, in mice knockout, specifically for miR-21 in hepatocytes, PPAR $\alpha$ expression was not altered, even when mice were challenged with an obesogenic diet, therefore suggesting that, in different cell types, miR-21 may have different activities and/or cellular targets [34, 72]. In hepatic stellate cells (HSCs), which are the main nonparenchymal liver cells contributing to the abnormal extracellular matrix deposition in liver fibrosis, miR-33 and miR$27 \mathrm{a} /-27 \mathrm{~b}$ were also found upregulated and to target PPAR $\alpha$ and the PPAR $\alpha$ cofactor RXR, respectively. Inhibition of these miRNAs with synthetic nucleotides in rat primary and immortalized human HSCs (LX-2 cells) increased PPAR $\alpha$ expression concomitantly with a decreased activation of the cells, thus suggesting a tight link between HSC activation and PPAR $\alpha$ expression $[35,73]$.

Hepatic Carcinogenesis. The role of PPAR $\alpha$ in cancer is still debated but few studies suggested that miRNAs-dependent alterations of PPAR $\alpha$ expression/activity are relevant for the development of hepatocellular carcinoma (HCC). In particular, high-throughput screening of human HCC samples 
revealed 28 miRNAs differentially expressed with top hits for miR-9, miR-21, and miR-224 [30]. In addition to miR21 , which is discussed in the previous section, prediction software programs identified conserved miR-9 binding sites within the $3^{\prime}$ UTR of PPAR $\alpha$. miR-9 upregulation correlated with tumor invasiveness, cell growth, and tumor stage, but whether this was related to a decreased PPAR $\alpha$ expression remains unclear. Indeed, whereas the direct regulation of PPAR $\alpha$ by miR- 9 in human HCC cells was confirmed by luciferase reporter assay [31], molecular analysis of human Snu-449 and HepG2 cancer cell lines indicated an indirect role for miR-9 overexpression in PPAR $\alpha$ downregulation [30].

\subsection{2. miRNAs-Dependent Regulation of PPAR $\alpha$ in the Adi-} pose Tissue. PPAR $\alpha$ assumes important functions in brown adipose tissue and adaptive thermogenesis and browning of white adipose tissue [41]. Although experimental evidence in human showing miRNAs-dependent PPAR $\alpha$ regulation in brown/white adipose tissue is scarce, several animal models have suggested such regulatory mechanisms. For example, miR-27a and miR-27b, which are downregulated in mouse brown/white adipose tissue after cold exposure, directly modulate components of the adipocyte transcriptional network including PPAR $\alpha$ [41]. MiR-519d, which is increased in subcutaneous white adipose tissue of obese subjects as compared to nonobese individuals, decreases fatty acid catabolism, and increases intracellular lipid accumulation by directly repressing PPAR $\alpha$ [39]. Finally, other miRNAs upregulated in brown adipose tissue and/or white adipose tissue of dietinduced obese mice, or during human white and beige adipose differentiation, for example, miR-106b/miR-93 [74, 75] and miR-26a and miR-26b [50], have been correlated with alterations of PPAR $\alpha$ expression. However, whether PPAR $\alpha$ is a direct target of these miRNAs was not investigated.

\subsection{3. miRNAs-Dependent Regulation of PPAR $\alpha$ in Other Cell Types/Organs}

Inflammatory Cells and Cartilage. Functional miRNAsdependent PPAR $\alpha$ alteration in inflammatory processes was suggested by two studies. First, miR-21, which is upregulated in cultured human endothelial cells from umbilical vein exposed to oscillatory shear stress, was shown to directly inhibit PPAR $\alpha$ translation [33]. The decreased expression of PPAR $\alpha$ in turn promotes AP1-dependent upregulation of VCAM-1 (vascular cell adhesion molecule-1) and MCP-1 (monocyte chemotactic protein-1), which favor the adhesion of inflammatory cells [33]. In a second study, bioinformatics and molecular analyses combined with clinical data identified an increased expression of miR-22 in osteoarthritic cartilage, which was correlated with PPAR $\alpha$ downregulation and an increased body-mass-index (BMI) of patients [76]. However, this study did not provide any direct molecular link between miR-22 upregulation and PPAR $\alpha$ downregulation.

Nonhepatic Cancers. The only evidence that PPAR $\alpha$ may potentially behave as a tumor suppressor downregulated by aberrantly expressed miRNAs in transformed cells comes from a study performed in a drug-resistant colon cancer cell line (SW1116) showing that miR-506 overexpression in this cancer cell model directly affects PPAR $\alpha$ expression [38]. In another study, the growth inhibitory properties of 1.25dihydroxyvitamin D3 in human prostate adenocarcinoma cells (LNCaP) were associated with an increased expression of the miR-17/92 cluster, which correlated with PPAR $\alpha$ downregulation, but whether miR-17/92 directly target PPAR $\alpha$ was not investigated [77].

3.2. miRNAs-Dependent Regulation of PPAR $\beta / \delta$. PPAR $\beta / \delta$ is ubiquitously expressed with the highest levels in liver, intestine, kidneys, and skeletal muscles [6, 78]. Major PPAR $\beta / \delta$ activators are natural ligands such as polyunsaturated fatty acids, prostaglandin derivatives (e.g., prostacyclin), or components of VLDL (Very Low Density Lipoproteins) particles [6]. This PPAR isoform regulates multiple cellular processes including developmental aspects, the lipid metabolism, insulin sensitivity, vascular function, and anti-inflammatory responses $[4,6,44,79]$. The best-characterized role of $\mathrm{PPAR} \beta / \delta$ has been described in metabolically active tissues. In the liver, $\operatorname{PPAR} \beta / \delta$ appears to increase glucose utilization through the pentose-phosphate pathway and to promote lipogenesis [80]. However, in mice fed an obesogenic diet, activation of PPAR $\beta / \delta$ surprisingly prevents the development of steatosis [81]. In muscles and white adipose tissue, PPAR $\beta / \delta$ exerts an adaptive response to fasting and exercise by favoring fatty acids oxidation [82], through the direct induction of key genes involved in this process (e.g., mitochondrial CPT-1 (Carnitine palmitoyltransferase-1) and FoxO1 (Forkhead box protein $\mathrm{O1})$ ) $[82,83]$. In brown adipose tissue, $\mathrm{PPAR} \beta / \delta$ contributes to adaptive thermogenesis by inducing the expression of UCP-1 and UCP-3 [81, 82] and to $\beta$-oxidation, by upregulating several genes involved in this process (e.g., long chain acyl-CoA synthetase, Acyl-CoA oxidase). In addition to these well established roles of $\operatorname{PPAR} \beta / \delta$, this isoform was further implicated in the regulation of multiple other cellular processes including developmental aspects, vascular function, and anti-inflammatory responses $[4,6,44,79]$. Finally, in cancer, the role of PPAR $\beta / \delta$ is controversial with evidence pointing at $\operatorname{PPAR} \beta / \delta$ as an oncogene (e.g., in breast and prostate tumors) [84] or as a tumor suppressor (e.g., in colon cancer) $[4,6,85]$. Despite the key functions of $\operatorname{PPAR} \beta / \delta$, solid experimental evidence indicating miRNAs-dependent regulation of this isoform is very limited and restricted to studies described below (see Table 1 and Figure 2).

3.2.1. miRNAs-Dependent Regulation of PPAR $\beta / \delta$ in the Liver. Based on Affymetrix microarrays, in vivo inhibition of miR122 by antisense oligonucleotides (ASO) in mice affected hundreds of hepatic mRNAs including PPAR $\beta / \delta$ [86]. Whether miR-122 directly targets $\mathrm{PPAR} \beta / \delta$ is still undetermined; however its downregulation following injection of miR-122 inhibitors in mice was suggested to affect circadian clockdependent energy homeostasis and in particular regulation of lipid transport and catabolism [86].

3.2.2. miRNAs-Dependent Regulation of PPAR $\beta / \delta$ in the Heart. By stimulating fatty acid utilization in the myocar- 
dium, $\operatorname{PPAR} \beta / \delta$ exerts a protective vascular function. In a mouse model of heart failure, an impaired fatty acid oxidation and a metabolic switch towards glycolysis were attributed to the direct repression of PPAR $\beta / \delta$ by two miRNAs, miR-199a and $\mathrm{miR}-214$, which are upregulated following aortic pressure overload and subsequent heart failure [43].

3.2.3. miRNAs-Dependent Regulation of PPAR $\beta / \delta$ in Monocytes/Macrophages. PPAR $\beta / \delta$ exerts an anti-inflammatory function, by promoting the switch from proinflammatory M1 macrophages to the anti-inflammatory M2 macrophages in the liver and in adipose tissue [44]. Bioinformatics and luciferase reporter assays revealed the presence of a functional miR-9 binding site within PPAR $\beta / \delta 3^{\prime} \mathrm{UTR}$ in human monocytes. Downregulation of $\mathrm{PPAR} \beta / \delta$ and its targets genes was further observed in proinflammatory M1 macrophages treated with lipopolysaccharide (LPS) and correlated with an upregulation of miR-9 in these cells, thus suggesting a potential functional regulation of $\operatorname{PPAR} \beta / \delta$ by miR- 9 in monocytes and macrophages [44].

3.2.4. miRNAs-Dependent Regulation of PPAR $\beta / \delta$ in Other Cell Types/Organs. MiRNAs-dependent $\mathrm{PPAR} \beta / \delta$ regulation was finally reported in hypertrophic scar formation, where $\operatorname{PPAR} \beta / \delta$ promotes proliferation of fibroblasts. A decrease in miR-138 expression was noted in scar tissue as compared to paired normal skin tissues and inversely correlated with the level of $\operatorname{PPAR} \beta / \delta$. Further analyses using luciferase reporter assays and synthetic miR-138 mimics and inhibitor nucleotides in human hypertrophic scar fibroblasts (hHSFs) confirmed that PPAR $\beta / \delta$ is a direct target of miR-138 and the functional relevance of this regulatory mechanism in hHSFs proliferation [45].

3.3. miRNAs-Dependent Regulation of PPAR $\gamma$. There are two $\operatorname{PPAR} \gamma$ isoforms (PPAR $\gamma 1$ and PPAR $\gamma 2$ ). PPAR $\gamma 1$ is broadly expressed in adipose tissue, liver, intestine, kidneys, small intestine, immune cells, and endothelium, while PPAR $\gamma 2$ is predominantly expressed in the adipose tissue $[2,3,6]$. Activation of PPAR $\gamma$ is induced mostly by unsaturated fatty acids and endogenous arachidonic acid-derived metabolites (e.g., leukotriene B4 and eicosatetraenoic acid). The bestdescribed functions of PPAR $\gamma$ are to transcriptionally promote adipocyte differentiation and lipogenesis as well as de novo lipogenesis in the liver $[5,87]$. In addition, $\operatorname{PPAR} \gamma$ controls also the expression of various adipocyte genes involved in glucose homeostasis (e.g., Glut4 expression) and endocrine signaling (e.g., adiponectin, resistin, and $\mathrm{TNF} \alpha$ ) affecting insulin sensitivity in other peripheral organs such as liver and muscles $[2,3,5,12]$. Finally, several other cellular processes including cholesterol transport, kidney function, food intake, and inflammation have been suggested to be modulated by PPAR $\gamma$ isoforms $[2,3,5,12]$. Consistent with the role of PPAR $\gamma$ in glucose and lipid homeostasis, an abnormal activity of PPAR $\gamma$ is often associated with the development of metabolic disorders (e.g., obesity, type 2 diabetes, and fatty liver disease) [5]. In contrast, in cancer, increasing evidence indicates a beneficial tumor suppressive role for $\operatorname{PPAR} \gamma$ (e.g., gastric, pancreatic, and hepatic cancers) [2, 6,
88]. As illustrated in Table 1 and Figure 2, posttranscriptional regulation of PPAR $\gamma$ by miRNAs has been reported in many pathophysiological situations.

\subsection{1. miRNAs-Dependent Regulation of PPAR $\gamma$ in the Liver}

Hepatic Fibrosis. PPAR $\gamma$ is a negative regulator of hepatic stellate cells (HSCs) activation [89]. The induction of various miRNAs expressed in nonalcoholic steatohepatitis (NASH) and fibrosis correlated with $\operatorname{PPAR} \gamma$ downregulation and overexpression of profibrogenic markers like $\alpha$-SMA. Among those miRNAs, upregulation of miR-34a/-34c [52], miR-128$3 \mathrm{p}$ [53], and $\mathrm{miR}-130 \mathrm{a} / \mathrm{miR}-130 \mathrm{~b}$ [63] in activated human or rat HSCs was reported to directly bind the $3^{\prime}$ UTR of $\operatorname{PPAR} \gamma$ and to repress its expression. miRNAs-dependent PPAR $\gamma$ downregulation in hepatic fibrosis can also occur through indirect mechanisms. For example, in HSCs from mice treated with CCL4 to induce fibrosis, miR-132 is downregulated thereby leading to an increase of one of its targets, MeCP2 (Methyl CpG binding protein 2), and repression of $\operatorname{PPAR} \gamma$ transcription via different epigenetic mechanisms [90].

Hepatitis C Virus (HCV) Infection. Infection of Huh-7.5 hepatoma cells with a HCV-derived JFH1 strain induces expression of miR-27a. This miRNA directly targets PPAR $\gamma$ thereby reducing lipid synthesis and increasing lipid secretion [91], two processes likely promoting $\mathrm{HCV}$ replication and virions egress.

Hepatic Carcinogenesis. PPAR $\gamma$ has a tumor suppressive function in hepatocarcinogenesis [7, 51, 92-95]. PPAR $\gamma$ downregulation in HCC correlated with upregulation of specific miRNAs $[3,93,96]$, among which the best characterized ones are $\mathrm{miR}-130 \mathrm{~b}$ and $\mathrm{miR}-27 \mathrm{a}$. These two miRNAs directly target $\operatorname{PPAR} \gamma$ and decrease its expression thus promoting cancer cells growth and aggressiveness $[47,55]$.

\subsection{2. miRNAs-Dependent Regulation of PPARy in Adipose Tissue}

Adipocyte Differentiation. Regulation of $\operatorname{PPAR} \gamma$ activity/ expression by miRNAs represents an important posttranscriptional mechanism controlling adipocyte differentiation. Several miRNAs in murine and human preadipocytes, including miR-540, miR-302a, miR-138, miR-548d-5p, miR130 , and miR-27, were described to bind the $3^{\prime}$ UTR of PPAR $\gamma$ and to decrease its expression thus preventing differentiation towards mature adipocytes $[54,57-59,67,97,98]$. In particular, miR-130 was reported to be downregulated in mice fed an obesogenic diet and in adipocytes of obese and type 2 diabetic patients, who also have high levels of PPAR $\gamma$ in adipose tissues and a low abundance of preadipocytes [54, 56, 62]. Further in vitro analyses using embryonic fibroblasts-derived preadipocytes (3T3-L1) indicated that synthetic nucleotides mimicking or inhibiting miR-130a were able to modulate PPAR $\gamma$ expression and its downstream target genes involved in glucose and lipid metabolism [56]. miR-27a and miR-27b are other key miRNAs regulating adipocyte differentiation, 
and both are downregulated during adipocyte differentiation, thus leading to an induction of PPAR $\gamma$ [59]. Consistent with this role, expression of miR-27a/-27b is lower in obese ob/ob mice as compared to lean animals and decreases during adipogenic differentiation of 3T3-Ll cells and mouse bone marrow derived mesenchymal stem cells (OP9 cell line). In the same study, miR-27a/miR-27b mimic nucleotides decreased PPAR $\gamma$ expression and prevented adipocyte differentiation. However, experimental evidence indicated that the mechanisms by which miR-27 affect PPAR $\gamma$ expression are indirect [98].

Inflammation. The role of PPAR $\gamma$ in adipose tissue inflammation is still poorly characterized, but downregulation of miR301a, which directly targets $\operatorname{PAAR} \gamma$, was correlated with the production of proinflammatory cytokines in obese mice and in 3T3L1 preadipocytes [65].

3.3.3. miRNAs-Dependent Regulation of PPAR $\gamma$ in Bone Marrow. The commitment of mesenchymal stem cells (MSCs) in the bone marrow towards osteogenic or adipogenic differentiation might be also tightly dependent on PPAR $\gamma$ regulation by miRNAs. Indeed, miR-548d-5p, which is downregulated during adipogenic differentiation of human bone marrow derived MSCs, targets the $3^{\prime} \mathrm{UTR}$ of PPAR $\gamma$. Overexpression of this miRNA abrogates adipogenic differentiation and increases the osteogenic potential of MSCs by downregulating PPAR $\gamma$ and $\mathrm{C} / \mathrm{EBP} \alpha$ [58]. Induction of other miRNAs such as miR-20 during osteogenic differentiation leads also to a direct downregulation of PPAR $\gamma$ [46]. In addition, miR$17-5 p$ and miR-106a also promote adipogenesis and inhibit osteogenic differentiation in human adipose derived MSCs by indirect mechanisms, which increase $\mathrm{C} / \mathrm{EBP} \alpha$ and PPAR $\gamma$ expressions [99]. Finally, alterations of the osteogenic/adipogenic differentiation balance is an important component of specific osteogenic-related disorders such as osteoporosis and deregulation of the expression of miRNAs targeting PPAR $\gamma$, for example, miR-210, have been involved in these diseases $[64,100]$.

3.3.4. miRNAs-Dependent Regulation of PPARY in the Heart. Upregulation of miR-27b expression was shown in heartspecific smad4 knockout mice, which develop cardiac hypertrophy [61]. Overexpression of this miRNA specifically in cardiomyocytes using transgenic mice was sufficient to induce cardiac hypertrophy through PPAR $\gamma$ downregulation [61]. Conversely, treatment of a mouse model of heart failure with miR-27b inhibitors (antagomirs) improved cardiovascular functions by increasing PPAR $\gamma$ expression [61]. Similarly, in vivo inhibition of miR-128 by antagomirs protected cardiomyocytes from apoptosis in a model of myocardial ischemia/reperfusion injury and increased PPAR $\gamma$ expression in neonatal rat ventricular myocytes (NRVM) [101]. However, whether miR-128 modulates PPAR $\gamma$ through direct or indirect mechanisms was not assessed in this study.

3.3.5. miRNAs-Dependent Regulation of PPAR $\gamma$ in Other Cell Types/Organs. In addition to its role in hepatocytes, adipocytes, and cardiomyocytes, the relevance of miR-27b targeting of PPAR $\gamma$ was also highlighted in several other tissues (inflammatory cells, renal tubular cells, and pulmonary endothelial cells as well as neuroblastoma).

Inflammatory Cells. PPAR $\gamma$ is a potent inhibitor of M1 macrophage activation (Th1 proinflammatory macrophages) and promoter of M2 macrophage activation (Th2 antiinflammatory macrophages) [102]. Upregulation of miR-27b in human macrophages upon LPS exposure was demonstrated to directly target PPAR $\gamma$ and to elicit a Th1 differentiation [49]. Although these findings suggest that miR-27bdependent downregulation of PPAR $\gamma$ may represent a key process in macrophage polarization, whether miR-27b controls M2 macrophage activation via $\operatorname{PPAR} \gamma$ was however not investigated.

Kidneys. Upregulation of miR-27a occurs in glucosestimulated rat renal proximal tubular cell line (NRK-52E cells) and renal tubular epithelial cells of streptozotocininduced diabetic rats. In these cellular contexts, the increased miR-27a expression was shown to trigger PPAR $\gamma$ downregulation, which in turn promoted renal fibrosis [60].

Lung. In mice and human pulmonary artery endothelial cells (HPAECs), hypoxia upregulates miR-27a expression and decreases PPAR $\gamma$ expression [103]. Given the important antiproliferative, and antithrombotic and vasodilatory effects of PPAR $\gamma$ on the lung vasculature [104], upregulation of miR-27a may thus represent an important contributor to the development of pulmonary hypertension.

Neuroblastoma Cells. Although miR-27b-dependent downregulation of PPAR $\gamma$ promotes cell proliferation in HCC, it may lead to opposite effects in other cancers [7, 51, 9295]. This is the case in the SK-N-AS neuroblastoma cells and derived mouse xenografts, where miR-27b was shown to repress PPAR $\gamma$ expression resulting in a decreased inflammatory response and tumor growth $[51,105,106]$.

\section{Indirect Regulation of PPARs by miRNAs}

The activity of PPARs is tightly linked to the binding of transcriptional partners (i.e., RXR, Prdm16), cofactors/repressors (e.g., PGCl $\alpha, \mathrm{NCOR}$ ), or other regulators (e.g., Sirtl) [3]. Most of the PPARs binding partners and cofactors are also finely tuned by specific miRNAs, which thereby indirectly regulate the expression/activity of PPARs isoforms [18, 107112]. A brief overview of miRNAs targeting PPARs binding partners and cofactors is provided in the next section (see Figure 3).

\section{1. miRNAs-Dependent Regulation of PPARs Binding/Heterodimerization Partners}

4.1.1. miRNAs-Dependent Regulation of RXRs. RXR isoforms $(\operatorname{RXR} \alpha / \beta / \gamma)$ are the obligate binding partners for PPARs. Together they form heterodimeric complexes and induce gene transactivation by binding to PPAR response elements (PPREs) [3]. As illustrated in Figure 3, several miRNAs have 


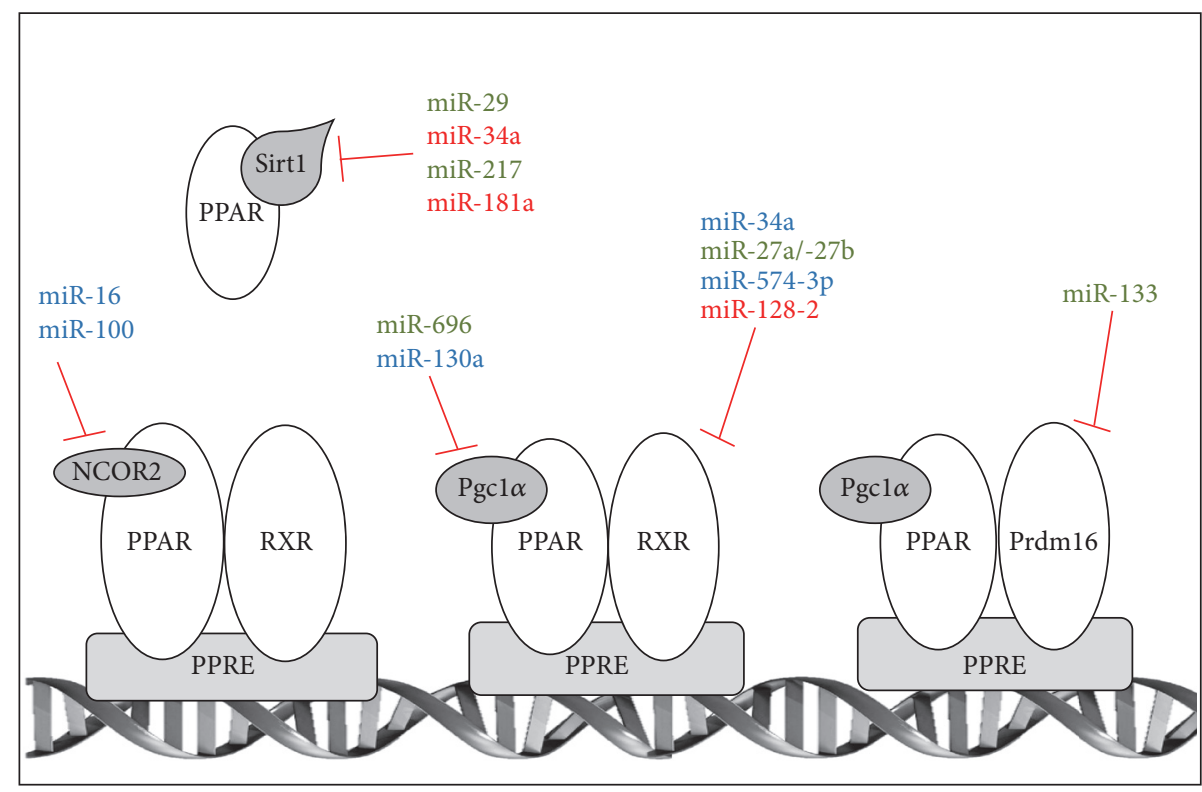

FIGURE 3: miRNAs targeting PPAR transcriptional partners, cofactors/repressors, and other regulators. miRNAs that have been experimentally demonstrated to specifically target PPAR transcriptional partners (RXR and Prdm16), PPAR cofactors (Pgcl $\alpha$ ), PPAR repressors (NCOR2), and other PPAR regulators (Sirt1) are illustrated. miRNAs identified in human studies are in blue, those identified in mouse/rat studies are in green, and those identified in both human and rodents studies are in red. PPAR: peroxisome proliferator-activated receptor $\alpha$, $\beta / \delta$, or $\gamma$; RXR: Retinoid-X-Receptor; Prdm16: PR domain-containing 16; Sirt1: Sirtuin-1; NCOR2: nuclear receptor corepressor 2 (SMRT); Pgcla: peroxisome proliferator-activated receptor gamma coactivator 1; PPRE: peroxisome proliferator response element.

been reported to directly target RXR isoforms thus affecting indirectly PPARs activities $[108,109,113,114]$. For example, miR-128-2 was shown to suppress cholesterol efflux in HepG2 cells and in the liver of diet-induced obese mice by binding to the $3^{\prime}$ UTR of RXR $\alpha$ and of ATP-binding cassette transporters (ABCA1 and ABCG1) and repressing their expressions [114]. Chondrogenesis, which is inhibited by $\mathrm{RXR} \alpha$, was also promoted in mesenchymal stem cells by miR-574-3p, which downregulates specifically $\mathrm{RXR} \alpha$ expression [113]. Interestingly, specific miRNAs targeting PPAR $\gamma$, that is, miR-34a and $\mathrm{miR}-27 \mathrm{a} / \mathrm{b}$, also control RXR $\alpha$ expression in liver cells $[73,98$, 109]. Indeed upregulation of miR-34a, which was correlated with fibrosis development, downregulates $\mathrm{RXR} \alpha$ by binding within the coding region and not the $3^{\prime} \mathrm{UTR}$ of this isoform in hepatocytes [109]. In the case of miR-27a and miR-27b, these two miRNAs were upregulated in rat activated HSCs and decrease RXR $\alpha$ expression through $3^{\prime} \mathrm{UTR}$-dependent mechanisms $[73,98]$. It thus appears that abnormal miRNAsdependent inhibition of RXR $\alpha$ in distinct liver cells contributes to the development of hepatic fibrogenesis. Finally, inhibition of RXR $\alpha$ by upregulation of miR-27a was also reported in aggressive rhabdomyosarcoma (RMS) [108]. Altogether, these studies suggest that particular miRNAs, such as miR-34a and the miR-27 family, may affect PPARs signaling by simultaneously targeting different key players in this pathway.

4.1.2. miRNAs-Dependent Regulation of Prdm16. During brown adipogenesis, Prdm16 (PR domain-containing 16) instead of RXR $\alpha$ heterodimerizes with PPAR $\gamma 2$ and mediates brown adipocyte differentiation [115]. MiR-133a was demonstrated to regulate directly Prdm16 expression in immortalized brown preadipocytes [18] and inhibition of miR-133a and miR-133b led to an increased expression of adipogenic markers including PPAR $\gamma$ as well as differentiation towards mature brown adipocytes $[18,116,117]$.

4.1.3. miRNAs-Dependent Regulation of PGC1 $\alpha$. PGCl $\alpha$ is a critical transcriptional coactivator of PPAR $\gamma$ in brown preadipocytes and of PPAR $\alpha$ in white preadipocytes (3T3-L1 cells) [118]. To date only two miRNAs have been described in hepatocytes to directly target PGCl $\alpha$ mRNA: (i) miR-696, which is upregulated with obesity, decreases PGCl $\alpha$ expression in the liver of ob/ob mice [119] and (ii) miR-130a, which is downregulated in HBV-infected human hepatocytes, increases PGCl $\alpha$ and PPAR $\gamma$ expression thus favoring HBV replication [120].

4.1.4. miRNAs-Dependent Regulation of NCOR. In the absence of PPARs ligands, the transcriptional activity of PPARs is inhibited by the binding of corepressors such NCOR proteins [12]. miRNAs-dependent regulation of NCOR proteins is supported by two studies showing that (i) miR-16 in LPS-activated human monocytes (U937) and biliary epithelial cells (H69) targets SMRT (NCOR2), which leads to NF- $\kappa$ B-mediated transactivation of the IL-8 gene [107], and (ii) miR-100 targets SMRT (NCOR2) in glioblastoma cells thereby inhibiting their proliferation [112]. 


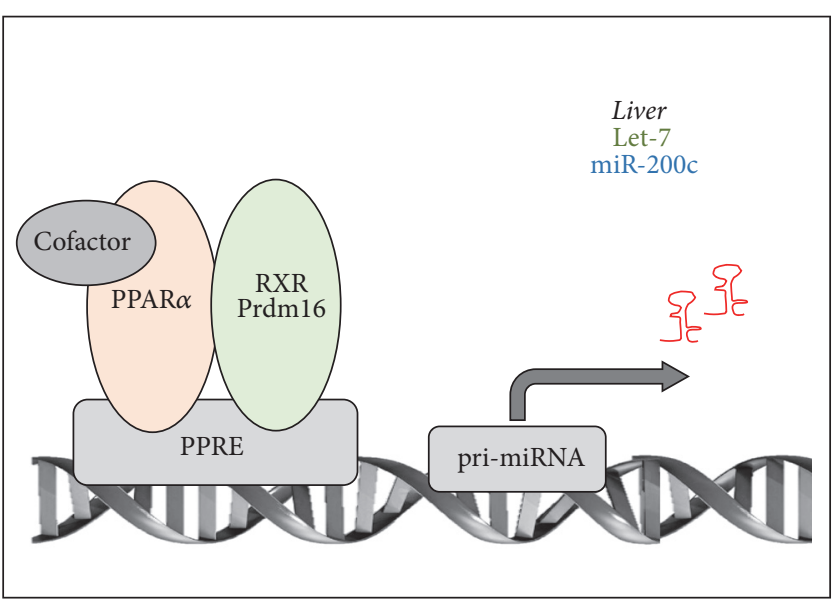

(a)

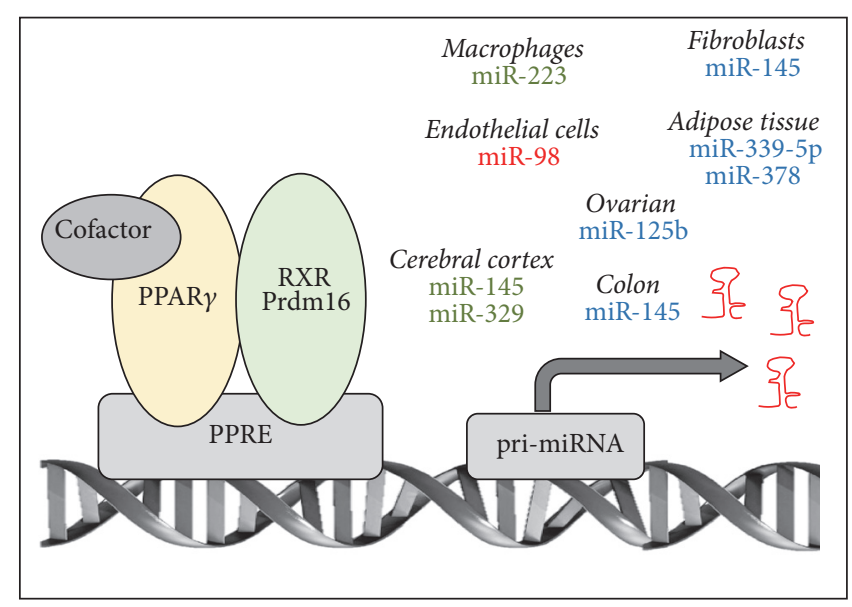

(b)

FIgURE 4: miRNAs expression induced by PPAR $\alpha$ and PPAR $\gamma$. Induction of miRNAs by PPAR $\alpha$ (Panel (a)) and PPAR $\gamma$ (Panel (b)) binding to PPRE in pri-miRNA promoters in specific tissues is indicated. miRNAs identified in human studies are in blue, those identified in mouse/rat studies are in green, and those identified in both human and rodents studies are in red. RXR: Retinoid-X-Receptor; Prdm16: PR domaincontaining 16; PPRE: peroxisome proliferator response element.

4.1.5. miRNAs-Dependent Regulation of Sirtuin-1. The NADdependent deacetylase Sirtuin-1 (Sirt1) is a critical regulator of PPAR signaling and of energy homeostasis [121]. Posttranscriptional control of SIRT1 and other sirtuins by miRNAs represents important regulatory mechanism for this protein family and has been extensively reviewed elsewhere [111]. Among the various miRNAs directly targeting SIRT1, miR217 [122], miR-181a [123], miR-29 [124], and miR-34a [125] in particular were shown to affect hepatic lipid metabolism, insulin sensitivity, or carcinogenesis by modulating SIRT1 expression. Of note, miR-34a is also a direct regulator of PPAR $\gamma$ and $\operatorname{RXR} \alpha$ expression [111, 125-128] therefore supporting again the biological relevance of fine-tuning PPARs signaling by modulating several factors involved in this transcriptional pathway.

\section{5. miRNAs Regulated by PPARs}

Recent evidence indicates that the expression of particular miRNAs can also be under the transcriptional control of PPARs [129] (see Figure 4). Most of the studies reviewed here rely on the identification of PPAR response elements (PPREs) within the promoter of genes encoding pri-miRNAs or on the effects of PPARs agonists [17, 96, 130, 131]. miRNAs described to date to be regulated by PPARs are short-listed in Table 2 .

5.1. PPAR $\alpha$ - and PPAR $\beta / \delta$-Dependent Regulation of miRNAs Expression. Limited information is available on PPAR $\alpha$ and PPAR $\beta / \delta$-dependent regulation of miRNAs expression. $\operatorname{PPAR} \alpha$ was suggested to promote the expression of let-7 and miR-200c in hepatic cancer cells. Indeed, expression of let7, which targets c-myc in hepatocytes, was decreased in mice treated with the PPAR $\alpha$ agonist Wy-14,643, which in turn fostered myc-dependent liver oncogenesis [71]. In Huh-7 hepatoma cells, PPAR $\alpha$ in synergy with another nuclear receptor, that is, LRH-1 (liver receptor homolog-1), was proposed also to drive miR-200c transcription through a direct binding to its promoter [132]. Although the role of miR-200c in HCC was not investigated in this study, miR-200 was previously shown to have tumor suppressive activities by inhibiting cell migration [135]. Regarding PPAR $\beta / \delta$, treatment of HUVEC endothelial cells with a PPAR $\beta / \delta$ agonist (GW501516) led to an increase of miR-100 expression, which improved lipidemia and vascular function [136]. However, as for the study using $\operatorname{PPAR} \alpha$ agonists, a direct binding of $\operatorname{PPAR} \beta / \delta$ to the miR-100 promoter was not investigated and additional experiments are required to confirm these data and exclude off-target effects of pharmacological agonists of $\operatorname{PPAR} \beta / \delta$.

5.2. PPAR $\gamma$-Dependent Regulation of miRNAs Expression. In contrast to the other PPAR isoforms, PPAR $\gamma$ was reported to regulate several miRNAs in distinct pathophysiological processes (see Table 2).

Endothelial Functions. miR-98, which is reduced in endothelial cells of patients suffering from idiopathic pulmonary hypertension (IPAH) and of mouse models of this disease, directly targets endothelin-1 (ET1). PPAR $\gamma$ was shown to exert a beneficial role in pulmonary hypertension $(\mathrm{PH})$ by attenuating, likely through activation of miR-98, ET1 expression. In support of this hypothesis, activation of PPAR $\gamma$ with specific agonists (e.g., rosiglitazone) restores miR-98 expression in hypoxic mouse and in primary human pulmonary artery endothelial cells (PAECs); however whether PPAR $\gamma$ is a direct regulator of miR-98 was not assessed [103].

Adipocytes Differentiation and Function. PPAR $\gamma$ agonists (rosiglitazone and pioglitazone) modulated the expression of 27 different miRNAs in human subcutaneous and visceral adipocytes. Among those, miR-329, miR-145, and miR-339$5 \mathrm{p}$ are involved, based on predictive bioinformatics analyses, 
TABLE 2: PPAR $\alpha$ - and PPAR $\gamma$-dependent miRNAs induction in specific tissues and pathophysiological processes.

(a) PPAR $\alpha$

\begin{tabular}{|c|c|c|c|c|}
\hline miRNA & Biological process & Organism & Cell/tissue & Reference \\
\hline Let-7 & Proliferation & Mouse & $\begin{array}{l}\text { Liver tissue, } \\
\text { HCC cell line }\end{array}$ & $\begin{array}{c}\text { Shah et al., } 2007 \\
\text { [71] }\end{array}$ \\
\hline miR-200c & Migration & Human & HCC cell line & $\begin{array}{l}\text { Zhang et al., } 2011 \\
{[132]}\end{array}$ \\
\hline \multicolumn{5}{|c|}{ (b) $\operatorname{PPAR} \gamma$} \\
\hline miRNA & Biological process & Organism & Cell/tissue & Reference \\
\hline miR-98 & $\begin{array}{l}\text { Endothelial dysfunction } \\
\text { Pulmonary hypertension }\end{array}$ & $\begin{array}{l}\text { Mouse } \\
\text { Human }\end{array}$ & $\begin{array}{c}\text { Primary pulmonary artery } \\
\text { endothelial cells }\end{array}$ & $\begin{array}{c}\text { Kang et al., } 2016 \\
{[103]}\end{array}$ \\
\hline miR-125b & $\begin{array}{c}\text { Proliferation } \\
\text { Apoptosis }\end{array}$ & Human & $\begin{array}{l}\text { Ovarian cancer tissue, } \\
\text { Ovarian cancer cell lines }\end{array}$ & $\begin{array}{c}\text { Luo et al., } 2015 \\
{[130]}\end{array}$ \\
\hline \multirow{3}{*}{ miR-145 } & $\begin{array}{l}\text { Inflammation } \\
\text { Oxidative stress }\end{array}$ & Rat & $\begin{array}{c}\text { Cerebral cortex, } \\
\text { Pheochromocytoma cell line }\end{array}$ & $\begin{array}{l}\text { Dharap et al., } \\
2015 \text { [17] }\end{array}$ \\
\hline & Collagen synthesis & Human & Hypertrophic scar fibroblasts & $\begin{array}{l}\text { Zhu et al., } 2015 \\
{[131]}\end{array}$ \\
\hline & $\begin{array}{c}\text { Cell cycle } \\
\text { Invasion } \\
\text { Differentiation }\end{array}$ & Human & $\begin{array}{l}\text { Colorectal cancer tissue and } \\
\text { colorectal cancer cell lines }\end{array}$ & $\begin{array}{l}\text { Panza et al., } \\
2014[96]\end{array}$ \\
\hline $\operatorname{miR}-223$ & Inflammation & Mouse & $\begin{array}{c}\text { Bone marrow derived macrophages } \\
\text { Adipocyte-derived stromal cells } \\
\text { Primary adipocytes }\end{array}$ & $\begin{array}{l}\text { Ying et al., } 2015 \\
{[133]}\end{array}$ \\
\hline miR-329 & $\begin{array}{c}\text { Inflammation } \\
\text { Oxidative stress }\end{array}$ & Rat & $\begin{array}{c}\text { Cerebral cortex, } \\
\text { Pheochromocytoma cell line }\end{array}$ & $\begin{array}{l}\text { Dharap et al., } \\
2015 \text { [17] }\end{array}$ \\
\hline miR-339-5p & $\begin{array}{c}\text { Adipocyte } \\
\text { differentiation }\end{array}$ & Human & $\begin{array}{l}\text { White adipose tissue } \\
\text { Isolated preadipocytes }\end{array}$ & $\begin{array}{c}\text { Yu et al. } 2014 \\
{[134]}\end{array}$ \\
\hline $\operatorname{miR}-378$ & $\begin{array}{l}\text { Adipocyte } \\
\text { differentiation }\end{array}$ & Human & $\begin{array}{c}\text { White adipose tissue } \\
\text { Primary adipose derived stromal } \\
\text { cells }\end{array}$ & $\begin{array}{c}\text { Yu et al., } 2014 \\
{[134]}\end{array}$ \\
\hline
\end{tabular}

in metabolic (e.g., insulin signaling) and proliferative (e.g., $\mathrm{Wnt} / \beta$-catenin signaling) pathways $[17,134]$. Interestingly, miR-329 and miR-145 contain a PPRE in their promoters and both miRNAs also bind to PPAR $\gamma 3^{\prime} \mathrm{UTR}$, thus suggesting the existence of positive feedback loop mechanisms regulating expressions of these miRNAs and PPAR $\gamma$ [17]. In human subcutaneous adipocytes and bovine preadipocytes, PPAR $\gamma$ also induces the expression of miR-378, which is located in the first intron of PPAR $\gamma$ coactivator-1 $\beta$ (PGC1 $\beta)[98,134$, 137]. Finally, a list of potential miRNAs, directly regulated by PPAR $\gamma$ and involved in 3T3-L1 adipose differentiation, was identified by crossing datasets of miRNAs containing putative PPAR $\gamma$ binding site with datasets of miRNAs altered during 3T3-L1 differentiation. Authors of this study identified miR-103-1, miR-182/miR-96/miR-183, miR-205, and miR-378 as potential PPAR $\gamma$-regulated miRNAs, whose expression was further induced in 3T3-L1 cells treated by rosiglitazone. Chip analyses also revealed that these miRNAs are directly regulated by PPAR $\gamma$ through PPRE present in their host genes $(\mathrm{PanK} 3$ and PGC1 $\beta$ ) [138].

Inflammation. Exposure of bone marrow derived macrophages (BMDMs) to Th2 stimuli (i.e., IL-4) triggers the expression of miR-223 through a direct binding of PPAR $\gamma$ in PPREs within the promoter of pre-miR-223. This effect was further enhanced by a $\operatorname{PPAR} \gamma$ agonist (i.e., pioglitazone) and inhibited by a PPAR $\gamma$ antagonist (i.e., GW9662). Since PPAR $\gamma$-dependent M2 activation is inhibited in BMDMs from miR-223 knockout mice, these data suggest that miR223 and its target genes (e.g., Rasal and genuine) are key effectors of macrophages polarization [133].

Fibrosis. Whether PPAR $\gamma$ may control fibrotic processes through miRNAs-dependent mechanisms is not well established, but one study supports this concept. Indeed, Dharap et al., reported that miR-145, which contains a PPAR response element in its promoter [17, 96], was increased in rosiglitazone-treated hypertrophic scar fibroblasts (HSFDs), thus leading to a direct decrease of SMAD3 expression and collagen synthesis [131].

Carcinogenesis. A direct effect of PPAR $\gamma$ on the expression of specific miRNAs through binding of PPRE in their promoters was demonstrated for three different types of cancer cell lines. In hepatoma HepG2 cells, miR-122 was strongly induced in cells treated with DNA methylation or histone deacetylase inhibitors via a direct binding of PPAR $\gamma / \mathrm{RXR} \alpha$ in the pre-miR-122 promoter [139]. In ovarian cancer cells (i.e., Ovcar3, CaOv3, and Skov3 cells), PPAR $\gamma$ also directly regulates the transcription of miR-125b and silencing of 
miR-125 impaired the growth inhibitory capacity of PPAR $\gamma$ agonists [130]. Finally, miR-145, which is downregulated in colorectal cancer cells (Caco2, Sw480, HCT116, and HT29) and colorectal tumor tissues, is induced by the PPAR $\gamma$ agonist (i.e., rosiglitazone) via direct binding of PPAR $\gamma$ to PPRE in the promoter encoding pre-miR-145 [96, 131].

\section{6. miRNAs-Based Therapies to Target PPARs Expression/Activity}

Targeting tissue-specific miRNAs with pharmacological compounds may represent novel and valuable alternative therapeutic approaches to PPAR agonists or antagonists [1013]. Different methods have been developed to modulate miRNA expressions in vivo. Of particular interest are chemically modified synthetic oligonucleotides inhibiting or mimicking endogenous miRNAs that display increased affinity for their targets and great stability in the serum. Currently, these oligonucleotides bear modifications on the $2^{\prime}$ - or $3^{\prime}$ position of the nucleic acid ribose backbone. For example, antagomiRs $\left(3^{\prime}\right.$-cholesterol-conjugated, $2^{\prime}$-O-Me oligonucleotides with terminal phosphorothioate modifications), antisense modified oligonucleotides (AMO) $\left(2^{\prime}\right.$-O-methoxyethyl phosphorothioate modified antisense oligonucleotide or $2^{\prime}$-fluoro-modified antisense oligonucleotides), or locked nucleic acids (LNA) represent potent inhibitors of miRNAs expression/activity. These synthetic nucleotides are usually administered by intravenous injection and hopefully soon orally with a good efficiency $[140,141]$. When administered by intravenous injection they can broadly reach every tissue but tends to accumulate in particular organs, such as the liver or the kidneys [26]. Special formulations such as liposomes or polyethylenimine-formulated nanoparticles as miRNA nanocarriers have been developed to improve tissuespecific distribution, circulation time, and clearance of the miRNAs-like compounds $[26,142,143]$. Of particular interest, microvesicles (MVs) were shown to represent efficient and functional miRNA delivery tools as it was demonstrated in animals and in the case of miR-130b $[144,145]$. Other alternative methods to target specific tissues have been also developed such as inclusion of oligonucleotides into liposomal or oleic-based nanoparticles, which target preferentially the liver [142]. Finally, viruses with specific tropisms, for example, adenoassociated viruses (AAV), have been used in animal models to robustly express or inhibit specific miRNAs in particular tissues and may represent an interesting alternative to chemically modified nucleotides [26]. Importantly, abnormal levels of circulating miRNAs stimulate toll-like receptors therefore promoting inflammation and favoring the development of chronic diseases such as metabolic and cardiovascular disorders as well as cancers. Interestingly, chemically modified synthetic oligonucleotides, in particular those modified in the $2^{\prime}$ position of the ribose, have the ability to reduce, but not completely prevent, such unintended immune responses $[26,146]$.

Several miRNA inhibitors have been tested in preclinical studies with rodents or primates in the context of various pathologies (e.g., miR-155 in inflammatory diseases, miR208 in cardiac remodeling) including metabolic diseases (e.g., miR-103/107 for type 2 diabetes and obesity) [26]. However, only few of them, for example, miR-122 inhibitors (Miravirsen) to treat HCV infection, are currently being tested in human clinical trials [26, 147-149]. Unfortunately, none of the miRNAs known to potentially target PPAR isoforms are under clinical trials in human. Only preclinical studies were performed for miR-33 and miR-21 [26], which targets directly PPAR $\alpha$ (Figures 2-3). In African green monkeys, inhibition of mir-33a/b with specific antagomiRs increased the hepatic expression of ABCA1, thus leading to an increase of HDL (high density lipoprotein) and a decrease in VLDL (very low density lipoproteins) and triglycerides plasma levels [150]. Inhibition of miR-21 in mice with an antisense oligonucleotide prevented hepatic lipid accumulation in animals fed an obesogenic diet [151].

The (pre)clinical use of synthetic nucleotides mimicking endogenous miRNAs is less developed compared to miRNAs inhibitors and currently only miR-34 mimics nucleotides are tested to treat some cancers $[26,152]$. MRX34, a liposomeformulated miR-34 mimic-based drug is currently in phase I study for melanoma patients. This miR-34 mimic achieved positive outcomes as a monotherapeutic agent in patients with renal cell carcinoma, acral melanoma, and HCC (http:// www.mirnatherapeutics.com/pipeline/mirna-pipeline.html) [26]. However, other in vivo studies indicated that miR-34a/c could also activate hepatic stellate cells and promote fibrogenesis by targeting PPARy and repressing RXR $\alpha$ and Sirtl [52, 109]. Other miRNAs, such as miR-27 or miR-9, are also able to regulate the expression/activities of different PPARs isoforms in distinct tissues. Therefore, although miRNAs-based therapies are promising, the potential pleiotropic effects of systemic administration of pharmacological miRNAs inhibitors or mimics call also for cautiousness in their therapeutic use since they can likely lead, as in the case of PPARs agonists/ antagonists, to conflicting and unwanted side effects.

\section{Conclusion}

The pivotal role of abnormal PPARs signaling in the development and the progression of various pathologies including metabolic diseases, inflammation, and cancer is now well established. However, the mechanisms and extent to which miRNAs contribute to alterations of PPARs expressions and/or activities in physiopathological conditions are currently still poorly understood and represent an important developing field of research. Conversely, the fact that PPARs can drive the expression of specific miRNAs, which may target in turn hundreds of different mRNAs, opens also a new dimension in our understanding of the physiological and pathological roles of PPARs isoforms. Given the tissuespecific and pleiotropic action of PPARs in various cellular processes described herein, it is likely that posttranscriptional regulation of PPARs and related cofactors by miRNAs is tissue- and process-specific. In addition, the simplistic view that only changes in the intracellular levels of miRNAs impact the expression of target genes is likely incorrect. Indeed increasing evidence indicates that the activity and bioavailability of miRNAs are also key factors to consider in these regulatory mechanisms. This concept is further 
supported by the emerging role of long noncoding RNAs [31] and RNA-binding proteins, which could interfere with the activity/expression of specific miRNAs $[153,154]$ and regulation of their target genes. Further studies are thus required to deepen our knowledge of miRNAs-based posttranscriptional regulatory mechanisms controlling PPARs expressions and activities.

\section{Abbreviations}

AP-1:

Activator protein-1

ApoA:

Apolipoprotein-A

BAT:

Brown adipose tissue

CD36:

Cluster of differentiation 36

FAT: Fatty acid translocase

$\mathrm{C} / \mathrm{EBP} \alpha: \quad \mathrm{CCAAT} / \mathrm{enh} \mathrm{Cn}$ cer-binding protein $\alpha$

C. elegans: Caenorhabditis elegans

COX-2: Cyclooxygenase-2

CRC: Colorectal carcinoma

CREB: $\quad$ CAMP response element-binding protein

CVD: Cardiovascular disease

DEN: Diethylnitrosamine

DGCR8: DiGeorge syndrome chromosomal region 8

ECM: $\quad$ Extracellular matrix

FABP: $\quad$ Fatty acid binding protein

Glut4: $\quad$ Glucose-transporter 4

HCC: Hepatocellular carcinoma

$\mathrm{HCV} / \mathrm{HBV}$ : Hepatitis C/B virus

HFD: High fat diet

HSC: Hepatic stellate cells

IRS-1/2: Insulin receptor substrates-1/2

lncRNA: Long noncoding RNA

LPL: $\quad$ Lipoprotein lipase

LPS: Lipopolysaccharide

LRH-1: $\quad$ Liver receptor homolog-1

MCP-1: Monocyte chemoattractant protein-1

miRNA: MicroRNA

MSC: $\quad$ Mesenchymal stem cell

NAFLD: Nonalcoholic fatty liver disease

NASH: Nonalcoholic steatohepatitis

NCOR: Nuclear receptor corepressor

ncRNA: Noncoding RNA

NF $\kappa$ B: $\quad$ Nuclear factor $\kappa$ B

PGE2: $\quad$ Prostaglandin E2

PGC1: Peroxisome proliferator-activated receptor gamma coactivator-1

PPAR: $\quad$ Peroxisome proliferator-activated receptor

PPRE: $\quad$ Peroxisome proliferator response element

Prdm16: PR domain-containing 16

RISC: $\quad$ RNA-induced silencing complex

ROS: $\quad$ Reactive oxygen species

RXR: Retinoid-X-Receptor

siRNA: $\quad$ Small interfering RNA

Sirtl: $\quad$ Sirtuin 1

SMRT: $\quad$ Silencing mediator for retinoid and thyroid hormone receptor

sncRNA: Small noncoding RNA

STAT1: $\quad$ Signal transducer and activator of transcription 1
T2DM: Type 2 diabetes mellitus

TARP2: T-cell receptor gamma-chain constant region

TNF- $\alpha$ : Tumor necrosis factor- $\alpha$

TZD: Thiazolidinedione

UCP-1: Uncoupling protein-1

UTR: Untranslated region

VCAM: Vascular cell adhesion protein

WAT: White adipose tissue.

\section{Competing Interests}

The authors declare that they have no competing interests.

\section{Authors' Contributions}

Dorothea Portius and Cyril Sobolewski have equal contributions.

\section{Acknowledgments}

Work in the Foti laboratory is supported by the Swiss National Science Foundation (Grant nos. 310030-152618 and CRSII3160717), the Swiss Cancer Research Foundation (Grant no. KFS-3246-08-2013), the Bo \& Kerstin Hjelt Diabetes Foundation, the FLAGS Foundation, the Fondation Romande pour la Recherche sur le Diabetes, and the EFSD/Lilly European Diabetes Research Programme.

\section{References}

[1] I. Issemann and S. Green, "Activation of a member of the steroid hormone receptor superfamily by peroxisome proliferators," Nature, vol. 347, no. 6294, pp. 645-650, 1990.

[2] R. M. Evans, G. D. Barish, and Y.-X. Wang, "PPARs and the complex journey to obesity," Nature Medicine, vol. 10, no. 4, pp. 355-361, 2004.

[3] S. Polvani, "Peroxisome proliferator activated receptors at the crossroad of obesity, diabetes, and pancreatic cancer," World Journal of Gastroenterology, vol. 22, no. 8, pp. 2441-2459, 2016.

[4] G. M. G. Attianese and B. Desvergne, "Integrative and systemic approaches for evaluating PPAR $\beta / \delta$ (PPARD) function," Nuclear Receptor Signaling, 2015.

[5] M. Ahmadian, J. M. Suh, N. Hah et al., "PPAR $\gamma$ signaling and metabolism: the good, the bad and the future," Nature Medicine, vol. 19, no. 5, pp. 557-566, 2013.

[6] B. Grygiel-Górniak, "Peroxisome proliferator-activated receptors and their ligands: nutritional and clinical implications-a review," Nutrition Journal, vol. 13, no. 1, article no. 17, 2014.

[7] J. M. Peters, Y. M. Shah, and F. J. Gonzalez, "The role of peroxisome proliferator-activated receptors in carcinogenesis and chemoprevention," Nature Reviews Cancer, vol. 12, no. 3, pp. 181-195, 2012.

[8] A. S. Laganà, S. G. Vitale, A. Nigro et al., "Pleiotropic actions of Peroxisome Proliferator-Activated Receptors (PPARs) in dysregulated metabolic homeostasis, inflammation and cancer: current evidence and future perspectives," International Journal of Molecular Sciences, vol. 17, no. 7, article 999, 2016. 
[9] E. Fuentes, L. Guzmán-Jofre, R. Moore-Carrasco, and I. Palomo, "Role of PPARs in inflammatory processes associated with metabolic syndrome (Review)," Molecular Medicine Reports, vol. 8, no. 6, pp. 1611-1616, 2013.

[10] C. J. Bailey, A. A. Tahrani, and A. H. Barnett, "Future glucoselowering drugs for type 2 diabetes," The Lancet Diabetes and Endocrinology, vol. 4, no. 4, pp. 350-359, 2016.

[11] B. Gross and B. Staels, "PPAR agonists: multimodal drugs for the treatment of type-2 diabetes," Best Practice and Research in Clinical Endocrinology and Metabolism, vol. 21, no. 4, pp. 687710, 2007.

[12] S. Sugii and R. M. Evans, "Epigenetic codes of PPAR $\gamma$ in metabolic disease," FEBS Letters, vol. 585, no. 13, pp. 2121-2128, 2011.

[13] C. V. Rizos, A. Kei, and M. S. Elisaf, "The current role of thiazolidinediones in diabetes management," Archives of Toxicology, vol. 90, no. 8, pp. 1861-1881, 2016.

[14] R. Barres and J. R. Zierath, "DNA methylation in metabolic disorders," American Journal of Clinical Nutrition, vol. 93, no. 4, pp. 897S-900S, 2011.

[15] K. Fujiki, F. Kano, K. Shiota, and M. Murata, "Expression of the peroxisome proliferator activated receptor $\gamma$ gene is repressed by DNA methylation in visceral adipose tissue of mouse models of diabetes," BMC Biology, vol. 7, article no. 38, 2009.

[16] M. K. Ramlee, Q. Zhang, M. Idris et al., "Histone H3 K27 acetylation marks a potent enhancer element on the adipogenic master regulator gene Pparg2," Cell Cycle, vol. 13, no. 21, pp. 3414-3422, 2014

[17] A. Dharap, C. Pokrzywa, S. Murali, B. Kaimal, and R. Vemuganti, "Mutual induction of transcription factor PPAR $\gamma$ and microRNAs miR-145 and miR-329," Journal of Neurochemistry, vol. 135, no. 1, pp. 139-146, 2015.

[18] W. Liu, P. Bi, T. Shan et al., "miR-133a regulates adipocyte browning in vivo," PLOS Genetics, vol. 9, no. 7, Article ID e1003626, 2013.

[19] V. Rottiers and A. M. Näär, "MicroRNAs in metabolism and metabolic disorders," Nature Reviews Molecular Cell Biology, vol. 13, no. 4, pp. 239-251, 2012.

[20] Z. Yang, T. Cappello, and L. Wang, "Emerging role of microRNAs in lipid metabolism," Acta Pharmaceutica Sinica B, vol. 5, no. 2, pp. 145-150, 2015.

[21] J. A. Deiuliis, "MicroRNAs as regulators of metabolic disease: pathophysiologic significance and emerging role as biomarkers and therapeutics," International Journal of Obesity, vol. 40, no. 1, pp. 88-101, 2016.

[22] C. L. Holley and V. K. Topkara, "An introduction to small noncoding RNAs: miRNA and snoRNA," Cardiovascular Drugs and Therapy, vol. 25, no. 2, pp. 151-159, 2011.

[23] S. L. Ameres and P. D. Zamore, "Diversifying microRNA sequence and function," Nature Reviews Molecular Cell Biology, vol. 14, no. 8, pp. 475-488, 2013.

[24] M. A. Goldgraben, R. Russell, O. M. Rueda, C. Caldas, and A. Git, "Double-stranded microRNA mimics can induce lengthand passenger strand-dependent effects in a cell type-specific manner," RNA, vol. 22, no. 2, pp. 193-203, 2016.

[25] C. Fernandez-Hernando, C. M. Ramírez, L. Goedeke, and Y. Suárez, "MicroRNAs in metabolic disease," Arteriosclerosis, Thrombosis, and Vascular Biology, vol. 33, no. 2, pp. 178-185, 2013.

[26] E. van Rooij and S. Kauppinen, "Development of microRNA therapeutics is coming of age," EMBO Molecular Medicine, vol. 6, no. 7, pp. 851-864, 2014.
[27] A. Lujambio and S. W. Lowe, "The microcosmos of cancer," Nature, vol. 482, no. 7385, pp. 347-355, 2012.

[28] G. A. Calin and C. M. Croce, "MicroRNA signatures in human cancers," Nature Reviews Cancer, vol. 6, no. 11, pp. 857-866, 2006.

[29] C. Sobolewski, N. Calo, D. Portius, and M. Foti, "MicroRNAs in fatty liver disease," Seminars in Liver Disease, vol. 35, no. 1, pp. 12-25, 2015.

[30] A. Drakaki, M. Hatziapostolou, C. Polytarchou et al., "Functional microRNA high throughput screening reveals miR-9 as a central regulator of liver oncogenesis by affecting the PPARACDH1 pathway," BMC Cancer, vol. 15, no. 1, article no. 542, 2015.

[31] M. Cui, Z. Xiao, Y. Wang et al., "Long noncoding RNA HULC modulates abnormal lipid metabolism in hepatoma cells through an mir-9-mediated RXRA signaling pathway," Cancer Research, vol. 75, no. 5, pp. 846-857, 2015.

[32] L. Zheng, G.-C. Lv, J. Sheng, and Y.-D. Yang, "Effect of miRNA$10 \mathrm{~b}$ in regulating cellular steatosis level by targeting PPAR- $\alpha$ expression, a novel mechanism for the pathogenesis of NAFLD," Journal of Gastroenterology and Hepatology, vol. 25, no. 1, pp. 156-163, 2010.

[33] J. Zhou, K.-C. Wang, W. Wu et al., "MicroRNA-21 targets peroxisome proliferators-activated receptor- $\alpha$ in an autoregulatory loop to modulate flow-induced endothelial inflammation," Proceedings of the National Academy of Sciences of the United States of America, vol. 108, no. 25, pp. 10355-10360, 2011.

[34] X. Loyer, V. Paradis, C. Hénique et al., "Liver microRNA-21 is overexpressed in non-alcoholic steatohepatitis and contributes to the disease in experimental models by inhibiting PPARa expression," Gut, vol. 65, no. 11, pp. 1882-1894, 2015.

[35] Z.-J. Li, P.-H. Ou-Yang, and X.-P. Han, "Profibrotic effect of miR-33a with Akt activation in hepatic stellate cells," Cellular Signalling, vol. 26, no. 1, pp. 141-148, 2014.

[36] W. Hu, X. Wang, X. Ding et al., "MicroRNA-141 represses HBV replication by targeting PPARA," PLoS ONE, vol. 7, no. 3, Article ID e34165, 2012.

[37] B. Li, Z. Zhang, H. Zhang et al., "Aberrant miR199a$5 \mathrm{p} /$ caveolin1/PPAR $\alpha$ axis in hepatic steatosis," Journal of Molecular Endocrinology, vol. 53, no. 3, pp. 393-403, 2014.

[38] J. L. Tong, C. P. Zhang, F. Nie et al., "MicroRNA 506 regulates expression of PPAR alpha in hydroxycamptothecin- resistant human colon cancer cells," FEBS Letters, vol. 585, no. 22, pp. 3560-3568, 2011.

[39] R. Martinelli, C. Nardelli, V. Pilone et al., "MiR-519d overexpression is associated with human obesity," Obesity, vol. 18, no. 11, pp. 2170-2176, 2010.

[40] P. Gurha, T. Wang, A. H. Larimore et al., "microRNA22 promotes heart failure through coordinate suppression of PPAR/ERR-nuclear hormone receptor transcription," PLoS ONE, vol. 8, no. 9, Article ID e75882, 2013.

[41] L. Sun and M. Trajkovski, "MiR-27 orchestrates the transcriptional regulation of brown adipogenesis," Metabolism: Clinical and Experimental, vol. 63, no. 2, pp. 272-282, 2014.

[42] D. Baek, J. Villén, C. Shin, F. D. Camargo, S. P. Gygi, and D. P. Bartel, "The impact of microRNAs on protein output," Nature, vol. 455, no. 7209, pp. 64-71, 2008.

[43] H. El Azzouzi, S. Leptidis, E. Dirkx et al., "The HypoxiaInducible MicroRNA Cluster miR-199a 214 targets myocardial PPAR $\delta$ and impairs mitochondrial fatty acid oxidation," Cell Metabolism, vol. 18, no. 3, pp. 341-354, 2013. 
[44] P. Thulin, T. Wei, O. Werngren et al., "MicroRNA-9 regulates the expression of peroxisome proliferator-activated receptor $\delta$ in human monocytes during the inflammatory response," International Journal of Molecular Medicine, vol. 31, no. 5, pp. 1003-1010, 2013.

[45] Y.-Y. Xiao, P.-J. Fan, S.-R. Lei, M. Qi, and X.-H. Yang, "MiR138/peroxisome proliferator-activated receptor $\beta$ signaling regulates human hypertrophic scar fibroblast proliferation and movement in vitro," Journal of Dermatology, vol. 42, no. 5, pp. 485-495, 2015.

[46] J.-F. Zhang, W.-M. Fu, M.-L. He et al., "MiRNA-20a promotes osteogenic differentiation of human mesenchymal stem cells by co-regulating BMP signaling," RNA Biology, vol. 8, no. 5, pp. 829-838, 2011.

[47] S. Li, J. Li, B.-Y. Fei et al., "MiR-27a promotes hepatocellular carcinoma cell proliferation through suppression of its target gene peroxisome proliferator-activated receptor $\gamma$," Chinese Medical Journal, vol. 128, no. 7, pp. 941-947, 2015.

[48] B.-Y. Kang, K. K. Park, D. E. Green et al., "Hypoxia mediates mutual repression between microRNA-27a and PPAR $\gamma$ in the pulmonary vasculature," PLoS ONE, vol. 8, no. 11, Article ID e79503, 2013.

[49] C. Jennewein, A. Von Knethen, T. Schmid, and B. Brüne, "MicroRNA-27b contributes to lipopolysaccharide-mediated peroxisome proliferator-activated receptor $\gamma(\operatorname{PPAR} \gamma)$ mRNA destabilization," Journal of Biological Chemistry, vol. 285, no. 16, pp. 11846-11853, 2010.

[50] M. Karbiener, C. Fischer, S. Nowitsch et al., "microRNA miR-27b impairs human adipocyte differentiation and targets PPARgamma," Biochemical and Biophysical Research Communications, vol. 390, no. 2, pp. 247-251, 2009.

[51] J.-J. Lee, A. Drakaki, D. Iliopoulos, and K. Struhl, "MiR-27b targets PPAR $\gamma$ to inhibit growth, tumor progression and the inflammatory response in neuroblastoma cells," Oncogene, vol. 31, no. 33, pp. 3818-3825, 2012.

[52] X. Li, Y. Chen, S. Wu et al., "MicroRNA-34a and microRNA-34c promote the activation of human hepatic stellate cells by targeting peroxisome proliferator-activated receptor $\gamma$," Molecular Medicine Reports, vol. 11, no. 2, pp. 1017-1024, 2015.

[53] D. Povero, N. Panera, A. Eguchi et al., "Lipid-induced hepatocyte-derived extracellular vesicles regulate hepatic stellate cells via microRNA targeting Peroxisome ProliferatorActivated Receptor- $\gamma$," CMGH Cellular and Molecular Gastroenterology and Hepatology, vol. 1, no. 6, pp. 646.e4-663.e4, 2015.

[54] E. K. Lee, M. J. Lee, K. Abdelmohsen et al., "miR-130 suppresses adipogenesis by inhibiting peroxisome proliferator-activated receptor $\gamma$ expression," Molecular and Cellular Biology, vol. 31, no. 4, pp. 626-638, 2011.

[55] K. Tu, X. Zheng, C. Dou et al., "MicroRNA-130b promotes cell aggressiveness by inhibiting peroxisome proliferator-activated receptor gamma in human hepatocellular carcinoma," International Journal of Molecular Sciences, vol. 15, no. 11, pp. 2048620499, 2014.

[56] Y. Jiao, M. Zhu, X. Mao et al., "MicroRNA-130a expression is decreased in Xinjiang Uygur patients with type 2 diabetes mellitus," American Journal of Translational Research, vol. 7, no. 10, pp. 1984-1991, 2015.

[57] Z. Yang, C. Bian, H. Zhou et al., "MicroRNA hsa-miR-138 inhibits adipogenic differentiation of human adipose tissuederived mesenchymal stem cells through adenovirus EID-1, Stem Cells and Development, vol. 20, no. 2, pp. 259-267, 2011.
[58] J. Sun, Y. Wang, Y. Li, and G. Zhao, "Downregulation of PPAR $\gamma$ by miR-548d-5p suppresses the adipogenic differentiation of human bone marrow mesenchymal stem cells and enhances their osteogenic potential," Journal of Translational Medicine, vol. 12, no. 1, article no. 168, 2014.

[59] S. Y. Kim, A. Y. Kim, H. W. Lee et al., "miR-27a is a negative regulator of adipocyte differentiation via suppressing PPAR $\gamma$ expression," Biochemical and Biophysical Research Communications, vol. 392, no. 3, pp. 323-328, 2010.

[60] X. Hou, J. Tian, J. Geng et al., "MicroRNA-27a promotes renal tubulointerstitial fibrosis via suppressing PPAR $\gamma$ pathway in diabetic nephropathy," Oncotarget, vol. 7, no. 30, pp. 4776047776, 2016.

[61] J. Wang, Y. Song, Y. Zhang et al., "Cardiomyocyte overexpression of miR-27b induces cardiac hypertrophy and dysfunction in mice," Cell Research, vol. 22, no. 3, pp. 516-527, 2012.

[62] C. Kim, H. Lee, Y. M. Cho, O.-J. Kwon, W. Kim, and E. K. Lee, “TNF $\alpha$-induced miR-130 resulted in adipocyte dysfunction during obesity-related inflammation," FEBS Letters, vol. 587, no. 23, pp. 3853-3858, 2013.

[63] L. Lu, J. Wang, H. Lu et al., "MicroRNA-130a and -130b enhance activation of hepatic stellate cells by suppressing PPAR $\gamma$ expression: a rat fibrosis model study," Biochemical and Biophysical Research Communications, vol. 465, no. 3, pp. 387-393, 2015.

[64] X.-D. Liu, F. Cai, L. Liu, Y. Zhang, and A.-L. Yang, "MicroRNA210 is involved in the regulation of postmenopausal osteoporosis through promotion of VEGF expression and osteoblast differentiation," Biological Chemistry, vol. 396, no. 4, pp. 339$347,2015$.

[65] H. Li, M. Xue, J. Xu, and X. Qin, "MiR-301a is involved in adipocyte dysfunction during obesity-related inflammation via suppression of PPAR $\gamma$," Pharmazie, vol. 71, no. 2, pp. 84-88, 2016.

[66] B.-C. Jeong, I.-H. Kang, and J.-T. Koh, "MicroRNA-302a inhibits adipogenesis by suppressing peroxisome proliferatoractivated receptor $\gamma$ expression," FEBS Letters, vol. 588, no. 18, pp. 3427-3434, 2014.

[67] L. Chen, Y. Chen, S. Zhang et al., "MiR-540 as a novel adipogenic inhibitor impairs adipogenesis via suppression of PPAR $\gamma$," Journal of Cellular Biochemistry, vol. 116, no. 6, pp. 969-976, 2015.

[68] M. Pawlak, P. Lefebvre, and B. Staels, "Molecular mechanism of PPAR $\alpha$ action and its impact on lipid metabolism, inflammation and fibrosis in non-alcoholic fatty liver disease," Journal of Hepatology, vol. 62, no. 3, pp. 720-733, 2015.

[69] P. Misra and J. K. Reddy, "Peroxisome proliferator-activated receptor- $\alpha$ activation and excess energy burning in hepatocarcinogenesis," Biochimie, vol. 98, no. 1, pp. 63-74, 2014.

[70] R. K. Lyn, R. Singaravelu, S. Kargman et al., "Stearoyl-CoA desaturase inhibition blocks formation of hepatitis $C$ virusinduced specialized membranes," Scientific Reports, vol. 4, article 4549, 2014.

[71] Y. M. Shah, K. Morimura, Q. Yang, T. Tanabe, M. Takagi, and F. J. Gonzalez, "Peroxisome proliferator-activated receptor $\alpha$ regulates a microRNA-mediated signaling cascade responsible for hepatocellular proliferation," Molecular and Cellular Biology, vol. 27, no. 12, pp. 4238-4247, 2007.

[72] N. Calo, P. Ramadori, C. Sobolewski et al., "Stress-activated $m i R-21 / m i R-21^{*}$ in hepatocytes promotes lipid and glucose metabolic disorders associated with high-fat diet consumption," Gut, vol. 65, no. 11, pp. 1871-1881, 2016. 
[73] J. Ji, J. Zhang, G. Huang, J. Qian, X. Wang, and S. Mei, “Overexpressed microRNA-27a and 27b influence fat accumulation and cell proliferation during rat hepatic stellate cell activation," FEBS Letters, vol. 583, no. 4, pp. 759-766, 2009.

[74] M. Karbiener and M. Scheideler, "MicroRNA functions in brite/brown fat-novel perspectives towards anti-obesity strategies," Computational and Structural Biotechnology Journal, vol. 11, no. 19, pp. 101-105, 2014.

[75] Y. Wu, J. Zuo, Y. Zhang et al., "Identification of miR-106b93 as a negative regulator of brown adipocyte differentiation," Biochemical and Biophysical Research Communications, vol. 438, no. 4, pp. 575-580, 2013.

[76] D. Iliopoulos, K. N. Malizos, P. Oikonomou, and A. Tsezou, "Integrative MicroRNA and proteomic approaches identify novel osteoarthritis genes and their collaborative metabolic and inflammatory networks," PLoS ONE, vol. 3, no. 11, article e3740, 2008.

[77] W.-L. W. Wang, J. E. Welsh, and M. Tenniswood, "1,25Dihydroxyvitamin $\mathrm{D}_{3}$ modulates lipid metabolism in prostate cancer cells through miRNA mediated regulation of PPARA," The Journal of Steroid Biochemistry and Molecular Biology, vol. 136, no. 1, pp. 247-251, 2013.

[78] L. Salvadó, L. Serrano-Marco, E. Barroso, X. Palomer, and M. Vázquez-Carrera, "Targeting PPAR $\beta / \delta$ for the treatment of type 2 diabetes mellitus," Expert Opinion on Therapeutic Targets, vol. 16, no. 2, pp. 209-223, 2012.

[79] S. A. Ross and C. D. Davis, "MicroRNA, nutrition, and cancer prevention," Advances in Nutrition, vol. 2, no. 6, pp. 472-485, 2011.

[80] C. H. Lee, P. Olson, A. Hevener et al., "PPARdelta regulates glucose metabolism and insulin sensitivity," Proceedings of the National Academy of Sciences of the United States of America, vol. 103, no. 9, pp. 3444-3449, 2006.

[81] Y.-X. Wang, C.-H. Lee, S. Tiep et al., "Peroxisome-proliferatoractivated receptor $\delta$ activates fat metabolism to prevent obesity," Cell, vol. 113, no. 2, pp. 159-170, 2003.

[82] E. Ehrenborg and A. Krook, "Regulation of skeletal muscle physiology and metabolism by peroxisome proliferatoractivated receptor $\delta$," Pharmacological Reviews, vol. 61, no. 3, pp. 373-393, 2009.

[83] B. Gross, M. Pawlak, P. Lefebvre, and B. Staels, "PPARs in obesity-induced T2DM, dyslipidaemia and NAFLD," Nature Reviews Endocrinology, vol. 13, no. 1, pp. 36-49, 2016.

[84] R. L. Stephen, M. C. U. Gustafsson, M. Jarvis et al., "Activation of peroxisome proliferator-activated receptor $\delta$ stimulates the proliferation of human breast and prostate cancer cell lines," Cancer Research, vol. 64, no. 9, pp. 3162-3170, 2004.

[85] J. M. Peters, F. J. Gonzalez, and R. Müller, "Establishing the Role of PPAR $\beta / \delta$ in Carcinogenesis," Trends in Endocrinology \& Metabolism, vol. 26, no. 11, pp. 595-607, 2015.

[86] D. Gatfield, G. Le Martelot, C. E. Vejnar et al., "Integration of microRNA miR-122 in hepatic circadian gene expression," Genes and Development, vol. 23, no. 11, pp. 1313-1326, 2009.

[87] M. Aprile, M. R. Ambrosio, V. D’Esposito et al., " $P P A R G$ in human adipogenesis: differential contribution of canonical transcripts and dominant negative isoforms," PPAR Research, vol. 2014, Article ID 537865, 11 pages, 2014.

[88] M. Pancione, L. Sabatino, A. Fucci et al., "Epigenetic silencing of peroxisome proliferator-activated receptor $\gamma$ is a biomarker for colorectal cancer progression and adverse patients' outcome," PLoS ONE, vol. 5, no. 12, Article ID el4229, 2010.
[89] M. Peyrou, P. Ramadori, L. Bourgoin, and M. Foti, "PPARs in liver diseases and cancer: epigenetic regulation by microRNAs," PPAR Research, vol. 2012, Article ID 757803, 16 pages, 2012.

[90] J. Mann, D. C. K. Chu, A. Maxwell et al., "MeCP2 controls an epigenetic pathway that promotes myofibroblast transdifferentiation and fibrosis," Gastroenterology, vol.138, no. 2, pp. 705.e4714.e4, 2010.

[91] T. Shirasaki, M. Honda, T. Shimakami et al., "MicroRNA27a regulates lipid metabolism and inhibits hepatitis $C$ virus replication in human hepatoma cells," Journal of Virology, vol. 87, no. 9, pp. 5270-5286, 2013.

[92] L. Q. Cao, X. L. Wang, Q. Wang et al., "Rosiglitazone sensitizes hepatocellular carcinoma cell lines to 5-fluorouracil antitumor activity through activation of the PPARgamma signaling pathway," Acta Pharmacologica Sinica, vol. 30, no. 9, pp. 1316-1322, 2009.

[93] J. Yu, B. Shen, E. S. H. Chu et al., "Inhibitory role of peroxisome proliferator-activated receptor gamma in hepatocarcinogenesis in mice and in vitro," Hepatology, vol. 51, no. 6, pp. 2008-2019, 2010.

[94] K. L. Schaefer, K. Wada, H. Takahashi et al., "Peroxisome proliferator-activated receptor $\gamma$ inhibition prevents adhesion to the extracellular matrix and induces anoikis in hepatocellular carcinoma cells," Cancer Research, vol. 65, no. 6, pp. 2251-2259, 2005.

[95] K. Yoshizawa, D. P. Cioca, S. Kawa, E. Tanaka, and K. Kiyosawa, "Peroxisome proliferator-activated receptor $\gamma$ ligand troglitazone induces cell cycle arrest and apoptosis of hepatocellular carcinoma cell lines," Cancer, vol. 95, no. 10, pp. 2243-2251, 2002.

[96] A. Panza, C. Votino, A. Gentile et al., "Peroxisome proliferatoractivated receptor $\gamma$-mediated induction of microRNA-145 opposes tumor phenotype in colorectal cancer," Biochimica et Biophysica Acta-Molecular Cell Research, vol. 1843, no. 6, pp. 1225-1236, 2014.

[97] B.-C. Jeong, I.-H. Kang, and J.-T. Koh, "MicroRNA-302a inhibits adipogenesis by suppressing peroxisome proliferatoractivated receptor $\gamma$ expression," FEBS Letters, vol. 588, no. 18, pp. 3427-3434, 2014.

[98] Q. Lin, Z. Gao, R. M. Alarcon, J. Ye, and Z. Yun, "A role of miR27 in the regulation of adipogenesis," FEBS Journal, vol. 276, no. 8, pp. 2348-2358, 2009.

[99] H. Li, T. Li, S. Wang et al., "MiR-17-5p and miR-106a are involved in the balance between osteogenic and adipogenic differentiation of adipose-derived mesenchymal stem cells," Stem Cell Research, vol. 10, no. 3, pp. 313-324, 2013.

[100] M. Sun, X. Zhou, L. Chen et al., "The regulatory roles of microRNAs in bone remodeling and perspectives as biomarkers in osteoporosis," BioMed Research International, vol. 2016, Article ID 1652417, 11 pages, 2016.

[101] C. S. Lutz and A. L. Cornett, "Regulation of genes in the arachidonic acid metabolic pathway by RNA processing and RNA-mediated mechanisms," Wiley Interdisciplinary Reviews: RNA, vol. 4, no. 5, pp. 593-605, 2013.

[102] A. Croasdell, P. F. Duffney, N. Kim, S. H. Lacy, P. J. Sime, and R. P. Phipps, "PPAR $\gamma$ and the innate immune system mediate the resolution of inflammation," PPAR Research, vol. 2015, Article ID 549691, 20 pages, 2015.

[103] B. Kang, K. K. Park, J. M. Kleinhenz et al., "Peroxisome proliferator-activated receptor $\gamma$ and microRNA 98 in hypoxiainduced endothelin-1 signaling," American Journal of Respiratory Cell and Molecular Biology, vol. 54, no. 1, pp. 136-146, 2016. 
[104] D. E. Green, R. L. Sutliff, and C. M. Hart, "Is peroxisome proliferator-activated receptor gamma (PPAR $\gamma)$ a therapeutic target for the treatment of pulmonary hypertension?" Pulmonary Circulation, vol. 1, no. 1, pp. 33-47, 2011.

[105] T. Liu, H. Tang, Y. Lang, M. Liu, and X. Li, "MicroRNA27a functions as an oncogene in gastric adenocarcinoma by targeting prohibitin," Cancer Letters, vol. 273, no. 2, pp. 233-242, 2009.

[106] Y. Tsuchiya, M. Nakajima, S. Takagi, T. Taniya, and T. Yokoi, "MicroRNA regulates the expression of human cytochrome P450 1B1," Cancer Research, vol. 66, no. 18, pp. 9090-9098, 2006.

[107] R. Zhou, X. Li, G. Hu, A.-Y. Gong, K. M. Drescher, and X.-M. Chen, "MiR-16 targets transcriptional corepressor SMRT and modulates NF-kappaB-regulated transactivation of interleukin8 gene," PLoS ONE, vol. 7, no. 1, Article ID e30772, 2012.

[108] L. Tombolan, M. Zampini, S. Casara et al., "MicroRNA-27a contributes to rhabdomyosarcoma cell proliferation by suppressing RARA and RXRA," PLoS ONE, vol. 10, no. 4, Article ID e0125171, 2015.

[109] Y. Oda, M. Nakajima, K. Tsuneyama et al., "Retinoid X receptor $\alpha$ in human liver is regulated by miR-34a," Biochemical Pharmacology, vol. 90, no. 2, pp. 179-187, 2014.

[110] M. J. Ochs, D. Steinhilber, and B. Suess, "MicroRNA involved in inflammation: control of eicosanoid pathway," Frontiers in Pharmacology, vol. 2, article no. 39, 2011.

[111] S.-E. Choi and J. K. Kemper, "Regulation of SIRT1 by microRNAs," Molecules and Cells, vol. 36, no. 5, pp. 385-392, 2013.

[112] B. M. Alrfaei, R. Vemuganti, and J. S. Kuo, "microRNA-100 targets SMRT/NCOR2, reduces proliferation, and improves survival in glioblastoma animal models," PLOS ONE, vol. 8, no. 11, Article ID e80865, 2013.

[113] D. Guérit, D. Philipot, P. Chuchana et al., "Sox9-regulated miRNA-574-3p inhibits chondrogenic differentiation of mesenchymal stem cells," PLoS ONE, vol. 8, no. 4, Article ID e62582, 2013.

[114] Y. K. Adlakha, S. Khanna, R. Singh, V. P. Singh, A. Agrawal, and N. Saini, "Pro-apoptotic miRNA-128-2 modulates ABCA1, ABCG1 and RXR $\alpha$ expression and cholesterol homeostasis," Cell Death \& Disease, vol. 4, article e780, 2013.

[115] P. Seale, B. Bjork, W. Yang et al., "PRDM16 controls a brown fat/skeletal muscle switch," Nature, vol. 454, no. 7207, pp. 961967, 2008.

[116] H. Yin, A. Pasut, V. D. Soleimani et al., "MicroRNA-133 controls brown adipose determination in skeletal muscle satellite cells by targeting Prdm16," Cell Metabolism, vol. 17, no. 2, pp. 210-224, 2013.

[117] M. Trajkovski, K. Ahmed, C. C. Esau, and M. Stoffel, "MyomiR133 regulates brown fat differentiation through Prdm16," Nature Cell Biology, vol. 14, no. 12, pp. 1330-1335, 2012.

[118] R. B. Vega, J. M. Huss, and D. P. Kelly, “The coactivator PGC1 cooperates with peroxisome proliferator-activated receptor $\alpha$ in transcriptional control of nuclear genes encoding mitochondrial fatty acid oxidation enzymes," Molecular and Cellular Biology, vol. 20, no. 5, pp. 1868-1876, 2000.

[119] Z. Fang, P. Li, W. Jia, T. Jiang, Z. Wang, and Y. Xiang, "miR696 plays a role in hepatic gluconeogenesis in ob/ob mice by targeting PGC-1 $\alpha$," International Journal of Molecular Medicine, vol. 38, no. 3, pp. 845-852, 2016.

[120] J.-Y. Huang, S.-F. Chou, J.-W. Lee et al., "MicroRNA-130a can inhibit hepatitis B virus replication via targeting PGC1 $\alpha$ and PPAR $\gamma$," RNA, vol. 21, no. 3, pp. 385-400, 2015.
[121] C. Cantó and J. Auwerx, “Targeting sirtuin 1 to improve metabolism: all you need is $\mathrm{NAD}^{+}$?" Pharmacological Reviews, vol. 64, no. 1, pp. 166-187, 2012.

[122] H. Yin, M. Hu, R. Zhang, Z. Shen, L. Flatow, and M. You, "MicroRNA-217 promotes ethanol-induced fat accumulation in hepatocytes by down-regulating SIRT1," Journal of Biological Chemistry, vol. 287, no. 13, pp. 9817-9826, 2012.

[123] B. Zhou, C. Li, W. Qi et al., "Downregulation of miR-181a upregulates sirtuin-1 (SIRT1) and improves hepatic insulin sensitivity," Diabetologia, vol. 55, no. 7, pp. 2032-2043, 2012.

[124] C. L. Kurtz, E. E. Fannin, C. L. Toth, D. S. Pearson, K. C. Vickers, and P. Sethupathy, "Inhibition of miR-29 has a significant lipidlowering benefit through suppression of lipogenic programs in liver," Scientific Reports, vol. 5, Article ID 12911, 2015.

[125] X.-F. Tian, F.-J. Ji, H.-L. Zang, and H. Cao, "Activation of the miR-34a/SIRT1/p53 signaling pathway contributes to the progress of liver fibrosis via inducing apoptosis in hepatocytes but not in HSCs," PLoS ONE, vol. 11, no. 7, Article ID e0158657, 2016.

[126] F. Zhang, J. Cui, X. Liu et al., "Roles of microRNA-34a targeting SIRT1 in mesenchymal stem cells," Stem Cell Research and Therapy, vol. 6, no. 1, article 195, 2015.

[127] A. L. McCubbrey, J. D. Nelson, V. R. Stolberg et al., "MicroRNA34 a negatively regulates efferocytosis by tissue macrophages in part via SIRT1," Journal of Immunology, vol. 196, no. 3, pp. 13661375, 2016.

[128] K. Duan, Y.-C. Ge, X.-P. Zhang et al., "miR-34a inhibits cell proliferation in prostate cancer by downregulation of SIRT1 expression," Oncology Letters, vol. 10, no. 5, pp. 3223-3227, 2015.

[129] X. Liu, X. Chen, X. Yu et al., "Regulation of microRNAs by epigenetics and their interplay involved in cancer," Journal of Experimental and Clinical Cancer Research, vol. 32, no. 1, article 96, 2013.

[130] S. Luo, J. Wang, Y. Ma, Z. Yao, and H. Pan, "PPAR $\gamma$ inhibits ovarian cancer cells proliferation through upregulation of miR125b," Biochemical and Biophysical Research Communications, vol. 462, no. 2, pp. 85-90, 2015.

[131] H.-Y. Zhu, C. Li, Z. Zheng et al., "Peroxisome proliferatoractivated receptor- $\gamma$ (PPAR- $\gamma$ ) agonist inhibits collagen synthesis in human hypertrophic scar fibroblasts by targeting Smad3 via miR-145," Biochemical and Biophysical Research Communications, vol. 459, no. 1, pp. 49-53, 2015.

[132] Y. Zhang, Z. Yang, R. Whitby, and L. Wang, "Regulation of miR200 c by nuclear receptors PPAR $\alpha$, LRH-1 and SHP," Biochemical and Biophysical Research Communications, vol. 416, no. 1-2, pp. 135-139, 2011.

[133] W. Ying, A. Tseng, R. C.-A. Chang et al., "MicroRNA-223 is a crucial mediator of PPAR $\gamma$-regulated alternative macrophage activation," Journal of Clinical Investigation, vol. 125, no. 11, pp. 4149-4159, 2015.

[134] J. Yu, X. Kong, J. Liu et al., "Expression profiling of PPAR $\gamma$ regulated MicroRNAs in human subcutaneous and visceral adipogenesis in both genders," Endocrinology, vol. 155, no. 6, pp. 2155-2165, 2014.

[135] C.-M. Wong, L. Wei, S. L.-K. Au et al., "MiR-200b/200c/429 subfamily negatively regulates Rho/ ROCK signaling pathway to suppress hepatocellular carcinoma metastasis," Oncotarget, vol. 6, no. 15, pp. 13658-13670, 2015.

[136] X. Fang, L. Fang, A. Liu, X. Wang, B. Zhao, and N. Wang, "Activation of PPAR- $\delta$ induces microRNA-100 and decreases the uptake of very low-density lipoprotein in endothelial cells," 
British Journal of Pharmacology, vol. 172, no. 15, pp. 3728-3736, 2015.

[137] S.-Y. Liu, Y.-Y. Zhang, Y. Gao et al., "MiR-378 plays an important role in the differentiation of bovine preadipocytes," Cellular Physiology and Biochemistry, vol. 36, no. 4, pp. 1552-1562, 2015.

[138] E. John, A. Wienecke-Baldacchino, M. Liivrand, M. Heinäniemi, C. Carlberg, and L. Sinkkonen, "Dataset integration identifies transcriptional regulation of microRNA genes by PPAR $\gamma$ in differentiating mouse 3T3-L1 adipocytes," Nucleic Acids Research, vol. 40, no. 10, pp. 4446-4460, 2012.

[139] K. Song, C. Han, J. Zhang et al., "Epigenetic regulation of microRNA-122 by peroxisome proliferator activated receptorgamma and hepatitis $\mathrm{b}$ virus $\mathrm{X}$ protein in hepatocellular carcinoma cells," Hepatology, vol. 58, no. 5, pp. 1681-1692, 2013.

[140] L. G. Tillman, R. S. Geary, and G. E. Hardee, "Oral delivery of antisense oligonucleotides in man," Journal of Pharmaceutical Sciences, vol. 97, no. 1, pp. 225-236, 2008.

[141] S. Mitragotri, P. A. Burke, and R. Langer, "Overcoming the challenges in administering biopharmaceuticals: formulation and delivery strategies," Nature Reviews Drug Discovery, vol. 13, no. 9, pp. 655-672, 2014.

[142] X. Wang, B. Yu, W. Ren et al., "Enhanced hepatic delivery of siRNA and microRNA using oleic acid based lipid nanoparticle formulations," Journal of Controlled Release, vol. 172, no. 3, pp. 690-698, 2013.

[143] C. J. Cheng, W. M. Saltzman, and J. F. Slack, "Canonical and non-canonical barriers facing antimiR cancer therapeutics," Current Medicinal Chemistry, vol. 20, no. 29, pp. 3582-3593, 2013.

[144] S. Pan, X. Yang, Y. Jia, R. Li, and R. Zhao, "Microvesicle-shuttled miR-130b reduces fat deposition in recipient primary cultured porcine adipocytes by inhibiting PPAR- $\gamma$ expression," Journal of Cellular Physiology, vol. 229, no. 5, pp. 631-639, 2014.

[145] S. Pan, X. Yang, Y. Jia et al., "Intravenous injection of microvesicle-delivery miR-130b alleviates high-fat diet-induced obesity in C57BL/6 mice through translational repression of PPAR- $\gamma$," Journal of Biomedical Science, vol. 22, article 86, 2015.

[146] F. Olivieri, M. R. Rippo, F. Prattichizzo et al., "Toll like receptor signaling in "inflammaging": microRNA as new players," Immunity and Ageing, vol. 10, article no. 11, 2013.

[147] R. E. Lanford, E. S. Hildebrandt-Eriksen, A. Petri et al., "Therapeutic silencing of microRNA-122 in primates with chronic hepatitis C virus infection," Science, vol. 327 , no. 5962, pp. 198201, 2010.

[148] S. Ottosen, T. B. Parsley, L. Yang et al., "In vitro antiviral activity and preclinical and clinical resistance profile of miravirsen, a novel anti-hepatitis $\mathrm{C}$ virus therapeutic targeting the human factor miR-122," Antimicrobial Agents and Chemotherapy, vol. 59, no. 1, pp. 599-608, 2015.

[149] J. Stenvang, A. Petri, M. Lindow, S. Obad, and S. Kauppinen, "Inhibition of microRNA function by antimiR oligonucleotides," Silence, vol. 3, no. 1, article 1, 2012.

[150] K. J. Rayner, C. C. Esau, F. N. Hussain et al., "Inhibition of miR$33 \mathrm{a} / \mathrm{b}$ in non-human primates raises plasma HDL and lowers VLDL triglycerides," Nature, vol. 478, no. 7369, pp. 404-407, 2011.

[151] H. Wu, R. Ng, X. Chen, C. J. Steer, and G. Song, "MicroRNA21 is a potential link between non-alcoholic fatty liver disease and hepatocellular carcinoma via modulation of the HBP1-p53Srebplc pathway," Gut, vol. 65, no. 11, pp. 1850-1860, 2015.

[152] M. Agostini and R. A. Knight, "miR-34: from bench to bedside," Oncotarget, vol. 5, no. 4, pp. 872-881, 2014.
[153] L. E. Young, A. E. Moore, L. Sokol, N. Meisner-Kober, and D. A. Dixon, "The mRNA stability factor HuR inhibits MicroRNA-16 targeting of COX-2," Molecular Cancer Research, vol. 10, no. 1, pp. 167-180, 2012.

[154] S. Geisler and J. Coller, "RNA in unexpected places: long noncoding RNA functions in diverse cellular contexts," Nature Reviews Molecular Cell Biology, vol. 14, no. 11, pp. 699-712, 2013. 


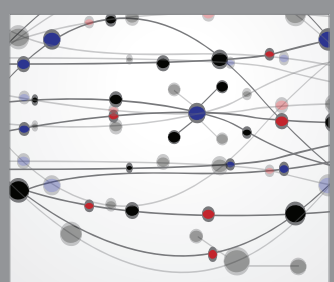

The Scientific World Journal
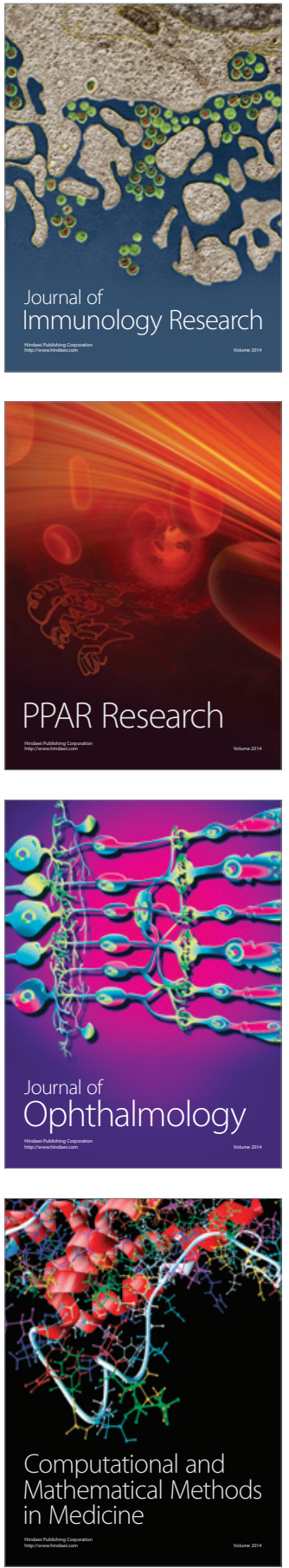

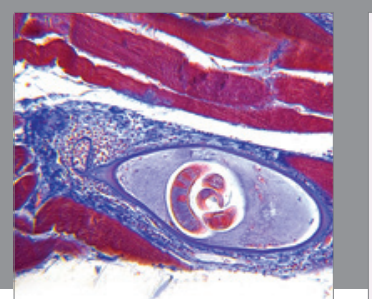

Gastroenterology Research and Practice
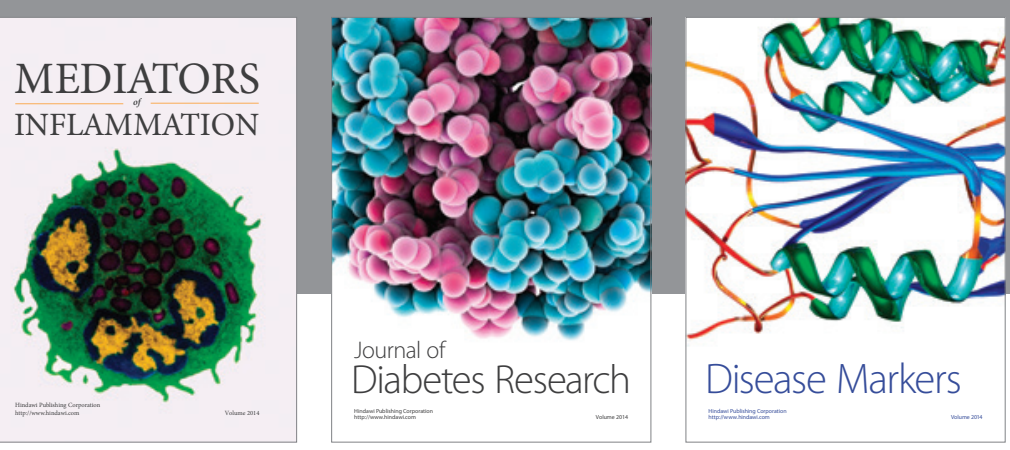

Disease Markers

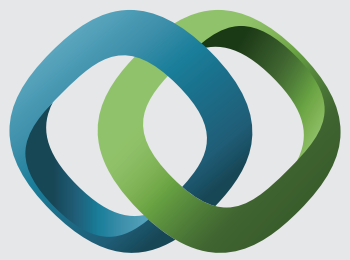

\section{Hindawi}

Submit your manuscripts at

https://www.hindawi.com
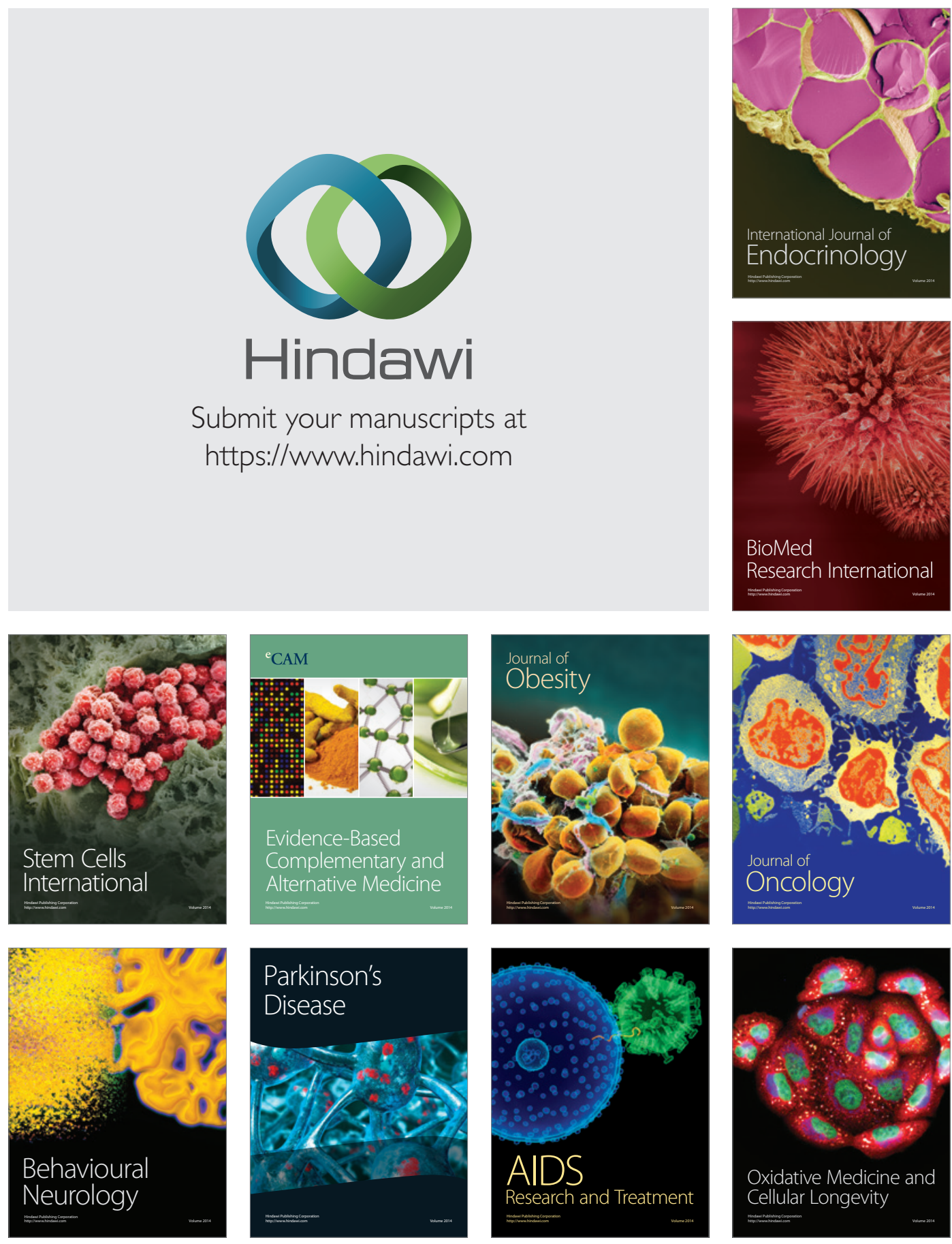